NBER WORKING PAPER SERIES

\title{
HOSTILITY IN TAKEOVERS: \\ IN TH EYES OF THE BEHOLDER?
}

\author{
G. William Schwert
}

Working Paper 7085

http://www.nber.org/papers/w7085

\author{
NATIONAL BUREAU OF ECONOMIC RESEARCH \\ 1050 Massachusetts Avenue \\ Cambridge, MA 02138 \\ April 1999
}

The Bradley Policy Research Center, William E. Simon Graduate School of Business Administration, University of Rochester, provided support for this research. I am indebted to Bob Comment for many discussions on this topic and for the use of his database. Comments from seminar participants at Columbia, Emory, Harvard, NYU, Yale, and the NBER Corporate Finance Conference are gratefully acknowledged. I also benefited from the suggestions of David Blackwell, Jarrad Harford, and Paul Healy. The views expressed herein are those of the authors and do not necessarily reflect the views of the National Bureau of Economic Research.

(0 1999 by G. William Schwert. All rights reserved. Short sections of text, not to exceed two paragraphs, may be quoted without explicit permission provided that full credit, including ${ }^{\circledR}$ notice, is given to the source. 
Hostility in Takeovers: In the Eyes of the Beholder?

G. William Schwert

NBER Working Paper No. 7085

April 1999

JEL No. G34

\begin{abstract}
This paper examines whether hostile takeovers can be distinguished from friendly takeovers, empirically, based on accounting and stock performance data. Much has been made of this distinction in both the popular and the academic literature, where gains from hostile takeovers are typically attributed to the value of replacing incumbent managers and the gains from friendly takeovers are typically attributed to strategic synergies. Alternatively, hostility could reflect just a perceptual distinction arising from different patterns of public disclosure, where negotiated outcomes are the rule and transactions tend to be characterized as friendly when bargaining remains undisclosed throughout, and hostile when the public becomes aware of the negotiation before its resolution. Empirical tests show that most deals described as hostile in the press are not distinguishable from friendly deals in economic terms, and that negotiations are publicized earlier in hostile transactions.
\end{abstract}

G. William Schwert

William E. Simon Graduate School of Business Administration

University of Rochester

Rochester, NY 14627

and NBER

Schwert@schwert.ssb.rochester.edu@cornell.edu 


\section{Introduction}

The perception of hostility in American takeovers has had important connotations in both the popular and the academic literature. Unwelcome bidders are often perceived to threaten at least some of the stakeholders in target corporations, which leads to extensive defensive reactions by the management of the target firm. In contrast, friendly takeovers are often seen to create synergies that make both the bidder and the target firm better off [see, for example, Mørck, Shleifer, and Vishny $(1988,1989)]$.

The distinction between hostile and friendly takeovers is also important if the gains from hostile takeovers are created by removing an inefficient target management team. Manne (1965) referred to this as part of the market for corporate control. Several papers have shown that management turnover increases following hostile takeovers, including Shivdasani (1993). While these theoretical polar cases seem intuitive, in practice most transactions contain elements of both friendly and hostile deals. That is, some stakeholders are likely to be disadvantaged by the transaction and there are likely to be some economic gains from combining the operations of the bidder and target.

Some laws and contracts depend on the distinction between hostile and friendly takeover attempts. For example, the Wall Street Journal (May 16, 1996) reports that Aon Corp. began selling "Hostile Takeover Defense Insurance," designed to reimburse companies for the costs associated with warding off a hostile takeover bid or a proxy fight with dissident shareholders. Likewise, Mitchell and Netter (1989) argue that a proposed tax bill that would have discouraged hostile takeovers contributed to the 1987 stock market crash.

Hostility is usually perceived when an offer is made public that is aggressively rejected by the target firm. Consequently, perceptions of hostility are closely linked with takeover 
negotiations that are far from completion. Often firms engage in confidential negotiations before there is a public announcement of a bid or an intention to bid. In some cases, the first public announcement is of a successfully completed negotiation, which would be perceived to be friendly, even if the early stage private negotiations would have seemed hostile if they had been revealed to the public. In other cases, private negotiations break down and one of the parties decides that public information about the potential bid would enhance its bargaining position. For example, bidders might choose to reveal their intentions to put stockholder pressure on target managers. Likewise, targets might reveal a takeover attempt to attract alternative bidders.

Because public announcements of takeover attempts are part of negotiating strategies, the problem of distinguishing between hostile and friendly transactions is complex. Moreover, as with any negotiation, the mood of the process can change over time as circumstances change. Many transactions that seem hostile initially result in friendly negotiated settlements.

This paper studies 2,346 offers for exchange-listed target firms from 1975-96 to see whether there are identifiable differences between offers that are characterized as hostile and those that are not. Hostility is measured as four different dichotomies based on (1) the way takeovers are characterized by the Wall Street Journal (WSJ) or Dow Jones News Retrieval (DJNR), (2) the way takeovers are characterized by Securities Data Corporation (SDC), (3) the use of unnegotiated tender offers, and (4) pre-bid takeover speculation. To determine whether there is economic substance to perceptions of hostility, I examine pre- and post-bid stock price and accounting performance of the target and bidder firms. I also consider the type of offer that is made, the mode of payment offered to target stockholders, and whether the bidding firm is also publicly traded. The differences seen in the data are consistent with the view that the distinction between hostile and friendly offers is largely a reflection of negotiation strategy. 
Section 2 describes the data sources and the practical definitions of hostility that will be tested. It also shows descriptive statistics across time and various types of deals. Section 3 contains estimates of probit models that use stock-price and accounting performance measures to predict whether a deal is characterized as hostile. Section 4 shows estimates of the relation between perceived hostility and the success rate of offers, the premiums paid to target shareholders, and the frequency of multiple bidder auctions. Section 5 contains concluding remarks.

\section{Measuring hostility and performance}

I examine five definitions of hostility, which are not mutually exclusive:

Host(WSJ) - If the WSJ Index or DJNR characterized the bid as hostile (at any time from 1975-98, including retrospective descriptions of the deal).

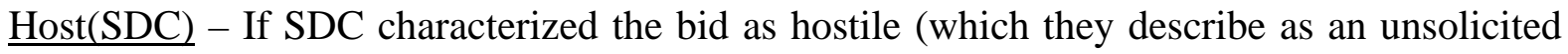
offer that is resisted by target management). This variable is available for 1,389 deals that I was able to match in the SDC database since 1980.

$\underline{\text { Host(Uns) }}$ - If there is either an unnegotiated tender offer for control of the target firm or a merger proposal that specifies a price (a "bear hug").

$\underline{\text { Host }(\operatorname{Pre})}$ - If during the 12 months before an initial bid, a 13D statement is filed in which the buyer discloses an intent to seek control, or there are significant merger rumors about the target firm (suggesting an effort to put the firm in play).

$\underline{\text { Host(Factor) }}$ - is the first factor or principal component from the set of three hostility variables with complete data [Host(WSJ), Host(Uns), and Host(Pre)]. This is a continuous variable that is scaled to be between 0 and 1 .

\subsection{Characteristics of hostile offers}

As seen in table 1, of the 2,346 successful and unsuccessful takeover bids for exchangelisted firms from 1975-96, 174 were characterized as hostile by DJNR [Host(WSJ)], 300 were 
characterized as hostile by SDC [Host(SDC)], 990 were hostile based on unnegotiated bids [Host(Uns)], and 1,043 were hostile based on pre-bid events [Host(Pre)].

There is some overlap in the transactions that are characterized as hostile by these measures of hostility. For each of the four hostility indicator variables, columns (4) through (7) of table 1 report differences in mean value within a sub-group as compared to the full sample, where sub-groups are defined by the hostility variables. For example, the value reported in the first row under column (5) is the mean value of Host(WSJ) among cases that are classified as hostile according to Host(SDC), less the mean value of Host(WSJ) among all cases. The t-test of significance is equivalent to a test of whether the mean of the observations in the subsample equals the mean of the observations not in the subsample.

The first three measures of hostility are strongly related, with weaker links to deals with pre-bid activity. For example, the t-statistic between Host(WSJ)] and Host(SDC) is 25.19 using cases based on Host(WSJ) and 12.32 using cases based on Host(SDC). There are similar strong relations for both WSJ and SDC measures of hostility with unsolicited offers [Host(Uns)]. The t-statistics relating pre-bid events with other measure of hostility are between 5.16 and 7.02 , which reflect weaker, but highly significant relations.

Table 2 shows the correlation coefficients among the four measures of hostility. It also shows the correlation of the hostility measures with a composite measure of hostility created from the first factor or principal component, Host(Factor), created from the three hostility measures with complete data, [Host(WSJ), Host(Uns), and Host(Pre)].

The correlation between the WSJ/DJNR measure of hostility and the SDC measure is strongest, at 0.502 . The correlations between the pre-bid measure of hostility Host(Pre) and the other measures are the smallest, between 0.152 and 0.212 . Thus, while the four alternative 
measures of hostility are positively associated, they are not highly correlated. The correlations with the hostility factor are larger, between .560 and .753 , suggesting that this construct may help identify what we mean by hostility better than the individual variables.

These pairwise comparisons show significant association, but the correlations are not as high as one would expect to find among alternative measures of a characteristic of corporate control transactions that is concrete, fundamental, exogenously determined, and self-evident. Yet, hostility is treated in much this way in both the popular press and most academic research. To further explore the possibility that the commonplace distinction between hostile and friendly transactions is more apparent than real, I use all four measures plus the composite factor in the tests below to determine whether the relations with other variables, such as takeover premiums, success rates, or auctions, help us identify an economic distinction among these measures of hostility.

\subsection{Time series behavior of hostile offers}

Figure 1 shows the total of the number of merger and tender offers for exchange-listed target firms each year from 1976-96, along with the annual number of transactions characterized as hostile, using the four definitions. The information on merger and acquisition announcements comes from Robert Comment's mergers \& acquisitions (M\&A) database, which covers all exchange-listed target firms in the period 1975-96. These announcements were obtained through various keyword searches of the DJNR database, inspection of the WSJ Index, and from Commerce Clearing House's Capital Changes Reporter (the original source for Center for Research in Security Prices (CRSP) delisting codes). In this study, I use the subset of records covering merger proposals, merger agreements, and interfirm tender offers. Merger proposals are distinguished from merger talks by a public disclosure of terms of purchase. An 
announcement qualifies as the initial one if there has been no other qualifying announcement in the prior year. The proportion of deals characterized as hostile by SDC is based on the subset of 1,389 offers that I identified on the SDC database.

About $7 \%$ of offers are characterized as hostile by WSJ/DJNR, with high rates of hostility from 1978-80, 1986-89, and 1995-96. The SDC database begins about 1980. SDC characterizes about $21 \%$ of deals as hostile, with the highest rates of hostile offers from 1982-89 and 1995-96. About $42 \%$ of offers are unsolicited [Host(Uns)], with a noticeable drop since 1992. The rate of pre-bid activity [Host(Pre)] also drops after 1992 to a level about half as high as during the 1980s. The rate of pre-bid activity showed relatively low levels from 1976-79, but this probably reflects measurement error as the WSJ Index did not cover rumors and 13D filings in as much detail as does the $D J N R$, the wire service with records available only since 1979. While the time series patterns of the alternate measures of hostility are similar, remember that the correlations among these measures are not large.

Figure 2 shows how the use of the word hostile has grown over time. Using DJNR, the solid line (plotted on the left axis) shows the number of stories containing the term "hostile takeover" for each year from November 1979 through June 1997, which grows from less than 50 stories in 1982 to more than 300 in recent years. To control for the growth in coverage by $D J N R$, the dashed line (plotted on the right axis) shows the proportion of takeover stories that included the adjective hostile. This varies in the range from 3-13\% since 1981. Thus, at least since the early 1980s, the term hostile has been a common term in the business press in relation to takeover strategy.

Table 3 shows the number of takeover bids by year from 1975-96 and tests, year-by-year, for whether the frequency of hostile bids within the population of exchange-listed firms differs 
from the frequency of all bids of any kind within this population, and does so separately for each of four measures of hostility. The formal statistical tests support the impressions gained from figure 1. After 1991, there was a statistically significant shift away from hostility comparable in magnitude to the shift towards hostility seen in the early 1980 's. ${ }^{1}$

\subsection{Characteristics of takeover deals}

Table 1 also shows several characteristics of takeover deals, including whether the target was successfully taken over (without more than a one year interval between bids), whether the target firm has a poison pill in place (Pill), whether other formal bids are made for this target firm (Auctions), whether the payment to target shareholders is all in the form of cash (Cash), whether the payment to target shareholders is all in the form of equity (Equity), whether the deal is a tender offer (Tender Offer), and whether the first or winning bidder is an exchange-listed company (Public Bidder). Poison pill information is from annual compilations contained in Corporate Control Alert, from various DJNR keyword searches, from Capital Changes Reporter, and from Moody's Manuals.

For many of the deal characteristics in table 1, the qualitative results are similar for different measures of hostility. For example, all types of hostility are positively associated with the possession of a poison pill by target firms, with t-statistics between 6.47 and 10.44 . On average, 9.3\% of targets have pills in the full sample, while deals labeled as hostile by SDC [Host(SDC)] have targets with pills $36.0 \%$ of the time $(0.093+0.267)$. It is difficult to assign causality here because the possibility of a hostile offer could lead firms to adopt defensive

1 This probably reflects the effects of antitakeover devices, such as poison pills and state antitakeover laws. In contrast, Comment and Schwert (1995) were unable to identify a statistically significant decline in hostile offers based on an analysis of transactions through 1991. 
measures, but the existence of a poison pill could indicate entrenched management in the target firm, or at least a tough negotiating stance.

Multiple-bidder auctions are more likely to be perceived as hostile, with t-statistics between 7.59 and 15.05. Again, it is difficult to assign causality, since a hostile bid could cause target management to seek a friendlier competing bidder (a white knight), or it might reflect the desire to improve the terms of the deal through competition. Bidders are more likely to be perceived as hostile when they use tender offers rather than merger proposals, with t-statistics between 3.34 and 12.22. Since multiple-bidder auctions tend to involve tender offers, however, it is unclear from these statistics whether these two factors have distinct contributions to perceptions of hostility (although the correlation between auctions and tender offers is only $0.202)$.

Cash is more likely to be offered as a means of payment in hostile offers, although this relation is weak for the measure of hostility based on pre-bid events [Host(Pre)], where the t-statistic is only 1.69. In parallel with the use of cash, hostile offers are less likely to offer only equity as compensation in hostile offers, with t-statistics between -6.97 and -15.47.

The bidder is less likely to be an exchange-listed public firm if the deal is hostile using the SDC, unsolicited, or pre-bid events measures [Host(SDC), Host(Uns), and Host(Pre), with t-statistics of $-2.73,-12.53$, and -5.71$]$, but slightly more likely to be a public firm if the offer is described as hostile by WSJ/DJNR [Host(WSJ), with a t-statistic of 1.88). This difference suggests that public bidders are less willing than are private bidders to engage in pre-bid activity and post-bid publicity that is perceived as hostile. The distinction between public bidders and private or foreign bidders could also reflect other important variables, such as the size of the 
target firm that is being sought, so any conclusions based on a simple comparison of means would be premature.

Finally, hostile offers are less likely to result in a successful takeover, even by another competing bidder. This effect is strongest for the unnegotiated deals [Host(Uns)], with a t-statistic of -15.14 . This presumably reflects both the resistance by target management and the fact that negotiated transactions that are first announced as successful transactions are less likely to fail.

Figure 3 (top panel) shows the rolling twelve month total of the number of merger and tender offers for exchange-listed target firms from 1976-96, along with the number of tender offers, the number of successful takeovers, the number of offers made by exchange-listed bidders, and the number of target firms with poison pills. The bottom panel of figure 3 shows the proportion of all offers that were tender offers, successful, had exchange-listed bidders, and where the target firms had poison pills. When hostile offers declined in the 1989-91 period, there was also a decline in success rates. The rate of tender offers declined from 1989 through mid-1993 before returning to pre-1984 levels. The rise since 1990 in the proportion of bidders that are public companies corresponds to the well-documented decline in LBO transactions, but could also show that the resources of large public bidders are more frequently necessary to combat evolving takeover defenses, as reflected in the rise in poison pills.

\subsection{Accounting performance of target firms}

Table 1 also shows the average accounting performance for target firms in the fiscal year before the first bid for the set of firms with data available on Compustat and CRSP (about 70\% 
of the sample). ${ }^{2}$ The variables used are:

return on equity (ROE) measured as the ratio of earnings to average equity for the prior fiscal year [Compustat items $20 /(60+60(t-1))]$,

sales growth measured as the proportional change in sales over the prior fiscal year $[\ln ($ Compustat item 12/12(t-1))],

liquidity measured as the ratio of net liquid assets to total assets for the prior fiscal year [Compustat items (4-5)/6],

debt/equity $(\boldsymbol{D} / \boldsymbol{E})$ measured as the ratio of debt to equity for the prior fiscal year [Compustat items 9/60],

market/book $(M / B)$ measured as the ratio of the year-end market value of common stock to the book value of equity for the prior fiscal year [Compustat items $24 \cdot 25 / 60$ ],

pricelearnings $(\boldsymbol{P} / \boldsymbol{E})$ measured as the ratio of the year-end stock price to earnings per share for the prior fiscal year [Compustat items 24/58], and

size measured as the log of equity capitalization (in thousands of dollars) at the start of the runup period, three months before the first bid [price times shares outstanding from CRSP].

Extreme outliers, such as market/book, price/earnings, or debt/equity ratios greater than 100, are omitted from the sample. These variables have been used to analyze the characteristics of target firms in many studies, including Palepu (1986) and Comment and Schwert (1995).

As a check on the robustness of the results, I also calculated alternative measures of accounting performance for target firms using variables suggested by Healy, Palepu and Ruback (1992). These variables had more missing data on Compustat than the variables shown above, so

2 Chan, Jegadeesh, and Lakonishok (1995) examine the reasons that firms are difficult to identify on Compustat using CUSIP numbers from the CRSP database and the effects, if any, of the resulting sample selection bias from analyzing only the firms on Compustat. Table 4, below, analyzes some of the effects of requiring full data in estimating the probit and regression models used in tables 5 through 9 later in this paper. 
the results were qualitatively similar, but weaker. Details are available from the author on request.

Firms that are large, as measured by market capitalization, are more likely to be the target of hostile offers, with t-statistics between 1.84 and 11.81. Deals that are characterized as hostile by $\operatorname{DJNR}[$ Host(WSJ)], for instance, have an average equity capitalization of $\$ 434$ million [exp(11.512+1.468)], compared to $\$ 100$ million [exp(11.512)] for the full sample. This could reflect a greater tendency for management entrenchment, and a correspondingly greater benefit from resistance, at large firms. Alternately, it could reflect relative weakness in the bargaining position of bidders when targets are large.

The only other performance measure that yields consistent results across the different measures of hostility is sales growth, with lower sales growth for targets that are the subject of hostile offers, ranging from $2.0 \%$ to $4.0 \%$ lower growth (compared with the average of $7.8 \%$ for the full sample), but the t-statistics are relatively small, between -1.42 and -3.49 . For hostile deals identified by DJNR [Host(WSJ)] and SDC [Host(SDC)], debt/equity (D/E) and market/book (M/B) ratios are lower than for the full sample, with t-statistics between -2.87 and -4.09 , but these differences are not repeated for the other measures of hostility. Return on equity (ROE) is lower for unnegotiated deals [Host(Uns)] compared with the full sample, with a t-statistic of -3.66, but this difference is not apparent for the other measures of hostility. Liquidity is lower for hostile deals with pre-bid events [Host(Pre)], with a t-statistic of -2.60 , , but this difference is not apparent for the other measures of hostility. Finally, the price/earnings (P/E) ratio is lower for hostile deals identified by $D J N R$ [Host(WSJ)] than for the full sample, with a t-statistic of -2.55 , but this difference is not repeated for the other measures of hostility. 
The results are somewhat stronger using the composite measure of hostility Host(Factor), which is a continuous variable scaled to be between 0 and 1 . Target firms that have performed poorly as reflected in low ROE, low sales growth, and a low stock price (relative to book value or earnings), are more likely to be the target of a hostile takeover attempt, with t-statistics between -2.59 and -3.65 . As before, larger targets are also more likely to be subject to hostile takeover attempts. Compared with the 1975-79 base period, hostile takeover attempts were more frequent from 1985-89 and less frequent from 1990-96, controlling for the performance of the target firm. About $13 \%$ of the variation in the composite hostility variable is explained by this regression.

Some of the differences in performance shown in table 1 are consistent with the notion that targets of hostile offers suffer disproportionately from entrenched management. For example, low values of the market/book ratio have been identified with poor use of the firm's assets [Lang, Stulz, and Walkling (1989)]. Low sales growth and ROE could also reflect inefficient use of corporate assets.

Jensen (1986) argues that poorly run target firms are likely to have too little debt, but there is no systematic relation between hostile takeover bids and the debt/equity ratio of the target firm. Similarly, Jensen also argues that poorly run firms are likely to have too many liquid assets (liquidity). The evidence in table 5, however, is inconsistent with this prediction. Harford (1999) and Opler, Pinkowitz, Stulz, and Williamson (1999) argue that it is important to measure deviations from "normal" cash balances when making comparisons across firms and time. Harford (1999) finds that firms with abnormally high cash balances are less likely to become takeover targets. Thus, at least for the liquidity variable, measurement issues could affect the results in table 5 . 


\subsection{Stock price performance of target firms}

There are 2,296 target firms with sufficient stock return data available on the CRSP database to measure the takeover premium realized by target stockholders associated with the takeover offers. I break the overall takeover premium into two parts, "runup" and "markup." The runup is measured as the market-adjusted return to the target's stock in the three months before the first bid [trading days $(-63,-1)$ relative to the first bid],

$$
\text { Runup }_{\mathrm{i}}=\sum_{t=-63}^{-1} \mathrm{R}_{\mathrm{it}}-\alpha_{\mathrm{i}}-\beta_{\mathrm{i}} \mathrm{R}_{\mathrm{mt}},
$$

where $\mathrm{R}_{\mathrm{it}}$ is the continuously compounded return to target firm $\mathrm{i}$ on trading day $\mathrm{t}$ relative to the announcement date of the initial takeover bid (day 0 ), $R_{m t}$ is the continuously compounded return to the CRSP value-weighted portfolio of New York, American, and Nasdaq-listed stocks on day $\mathrm{t}$, and the market model regression parameters, $\alpha_{\mathrm{i}}$ and $\beta_{\mathrm{i}}$, are estimated using data for the 253 trading days ending at day -64 ,

$$
\mathrm{R}_{\mathrm{it}}=\alpha_{\mathrm{i}}+\beta_{\mathrm{i}} \mathrm{R}_{\mathrm{mt}}+\varepsilon_{\mathrm{it}}, \quad \mathrm{t}=-316, \ldots,-64 .
$$

The markup is measured as the market-adjusted return to the target's stock in the six months after the first bid [trading days $(0,126)$ relative to the first bid], and the premium is the sum of the runup and the markup. ${ }^{3}$

The runup return is $4.7 \%$ higher than average (t-statistic of 4.56 ) for hostile offers identified by pre-bid events [Host(Pre)], which is not surprising since these pre-bid events foreshadow a possible bid. On the other hand the runup return is $2.2 \%$ lower than average t-statistic of -2.17) for unnegotiated bids [Host(Uns)], which could reflect leakage of information

3 Schwert (1996) analyzes the relation between runups and markups for a large sample of exchange-listed takeover attempts. As a robustness check, I also calculate markups and premiums using a markup period of ten trading days after the initial bid date. None of the results change substantially, so these results are not reported in detail. 
associated with some negotiated takeover bids. There is no reliable difference in runup return for hostile deals identified by DJNR [Host(WSJ)] or SDC [Host(SDC)].

The markup return is $8.1 \%$ lower than average (t-statistic of -6.02) for deals with pre-bid events [Host(Pre)], but it is $12.2 \%$ and $5.1 \%$ higher than average (t-statistics of 5.40 and 2.36) for deals identified by $D J N R$ [Host(WSJ)] and SDC [Host(SDC)], respectively. The net effect is that the total premium, runup plus markup, is $11.5 \%$ and $6.7 \%$ higher (t-statistics of 4.46 and 2.53) for deals identified by $D J N R$ [Host(WSJ)] and SDC [Host(SDC)], but it is not reliably different from the full sample for the other measures of hostility.

\subsection{Sample selection bias}

In later sections I analyze the relation between hostility and success rates, the likelihood of an auction, and the size of the runup and premium controlling for the effects of prior target performance. Where appropriate, I also control for the characteristics of the deal. These conditional tests allow for a better understanding of the role that hostility plays in takeovers. In the probit and regression models I estimate, however, I require full data on the explanatory variables. As shown in table 1, the data sources do not have complete information on accounting and stock price performance for many firms. In fact, only 593 of the 2,346 (25.3\%) possible cases have data on all six measures of accounting performance (ROE, Sales Growth, Liquidity, $\mathrm{D} / \mathrm{E}, \mathrm{M} / \mathrm{B}$, and $\mathrm{P} / \mathrm{E}$ ) available from Compustat along data on target stock price behavior (Runup, Markup, Premium, and Size) available from CRSP. If I omit the SDC measure of hostility, which I can only observe in 1,389 (59.2\%) of the cases, there are 1,096 cases with full data available.

Table 4 shows a comparison of means between the full sample and the sample with full data available for each of the variables in tables 1 and 2, along with heteroskedasticity-consistent 
t-statistics. Among the hostility variables, the deals identified as hostile by DJNR and based on pre-bid events occur more frequently in the sample with complete data (t-statistics of 2.93 and 3.94). This is not surprising, since $D J N R$ devotes more coverage to large and more prominent firms. Since the composite hostility factor, Host(Factor), is a linear combination of Host(WSJ), Host(Uns), and Host(Pre), it is not surprising that it is also larger in the sample with full data. The deals identified as hostile by SDC are also more likely in the probit sample than in the unconditional sample (t-statistic of 3.11).

Cash offers and tender offers also occur more frequently in the sample with complete data (t-statistics of 2.48 and 3.77). Return of equity (ROE), sales growth, and P/E ratios are all higher for the sample with complete data (t-statistics of 8.70, 4.17, and 7.17), implying that these target firms have had better recent performance than the firms with some missing data. Likewise, firms with complete data are larger and have lower D/E ratios (t-statistics of 13.57 and -4.23). Finally, average runups are lower and markups are higher for the firms with complete data (t-statistics of -2.32 and 1.94).

The proportion of target firms with complete data is lower than for the full sample in table 2 between 1976-81 (t-statistics between -4.66 and -11.15). This is largely due to the lack of SDC data before 1980.

The results in table 4 suggest caution in interpreting the subsequent tests that condition takeover events on accounting or stock market performance. The sample of firms that have complete data available for analysis is systematically different from the set of all 2,346 target firms. On average, target firms are larger and more prosperous, and hostility seems to occur more frequently. At a minimum, we should be cautious in extrapolating the findings to smaller, less prosperous target firms. 


\section{Is hostility related to prior performance?}

Many papers have sought a relation between the prior performance of target firms and the likelihood that they receive a takeover bid [e.g., Hasbrouck (1985), Palepu (1986), Mørck, Shleifer, and Vishny (1988), Mikkelson and Partch (1989), Shivdasani (1993), and Comment and Schwert (1995)]. I ask a related question: Conditional on an offer being received by a target firm, what is the probability that it will be hostile?

\subsection{Previous studies of takeover probabilities}

Hasbrouck (1985) uses a logit model to predict takeovers for a sample of 86 targets and a sample of 344 time-, size- and industry-matched non-targets, and finds that larger market/book ratios and larger size reduce the likelihood of a takeover, but that liquidity and leverage are unimportant. Palepu (1986) provides logit estimates based on a sample of 163 target and 256 non-target firms in the period 1971-79 using accounting and stock-based predictors similar to those described in section 2. He obtains negative coefficient estimates for sales growth, leverage, and size, so these reduce the likelihood of a takeover. Market/book, price/earnings, and liquidity do not affect the likelihood of a takeover.

Mørck, Shleifer, and Vishny (1988) estimate a probit model using 1980 data for 454 Fortune-500 firms, of which 82 were takeover targets between 1981-85, and find that larger size and market/book ratios deter hostile takeovers, but not friendly ones. Mikkelson and Partch (1989) use a logit model and pool data as of 1973, 1978, and 1983 for 240 exchange-listed firms. They find that larger size and affiliate-firm cross-holdings deter acquisitions, but that leverage and managerial stockholdings do not affect the likelihood of a successful takeover. Shivdasani (1993) estimates a logit model using data on 193 hostile targets and 194 non-target firms from 
1980-88 and finds that size, managerial stockholdings, and affiliate-firm cross-holdings deter hostile takeovers, but that earnings growth and board composition do not matter.

Comment and Schwert (1995) estimate a probit model using 21,887 firm-years of data for all exchange-listed firms with the requisite CRSP and Compustat data from 1976-91. Their sample includes 669 successful takeovers. They find size is negatively related to takeover probability, but that none of the other performance variables are reliable predictors. Thus, size is the only predictor that is consistently successful in these studies, while mixed success has been achieved with sales growth, leverage, market/book, and certain ownership variables.

\subsection{Probit models for hostility}

Table 5 shows estimates of probit models that predict whether a takeover offer is characterized as hostile by DJNR [Host(WSJ)], by SDC [Host(SDC)], is unnegotiated [Host(Uns)], or is preceded by events that imply that the target firm is in play [Host(Pre)]. It also shows a regression model that predicts the continuous composite hostility variable, Host(Factor). The variables included in the probit and regression models include the performance variables in table 1 (ROE, sales growth, liquidity, debt/equity, market/book, price/earnings, and size). To allow for secular variation in the behavior of the takeover market that is not captured by the other variables, dummy variables for 1980-84, 1985-89, and 1990-96 are included that equal one if the deal is announced in these years, and zero otherwise (so that 1975-79 is the base comparison period reflected in the intercept of the model). Note that the sample size for Host(SDC) is much smaller (593) than for the other hostility variables $(1,096)$.

Table 5 reports maximum likelihood estimates of the probit coefficients and t-statistics based on large sample standard errors. Since probit coefficients are difficult to interpret, 
table 5 also reports the marginal effect of a change in each predictor variable calculated at its sample mean (i.e., similar to the least squares coefficient in a linear probability model). ${ }^{4}$

Consistent with the results in table 1 , the size of the target firm is positively related to the likelihood that an offer will be hostile, with t-statistics of $7.49,5.68,1.11,4.29$, and 6.73 for the five measures of hostility. An increase of \$25.6 million in equity capitalization, which averages $\$ 112.9$ million in this sample, increases the probability of an offer being characterized as hostile by $D J N R$ [Host(WSJ)] by $1 \%$.

The other variables do not have a consistent and reliable effect across measures of hostility. For example, M/B is negatively related to hostility based on SDC identification [Host(SDC)] and unnegotiated offers [Host(Uns)], with t-statistics of -2.83 and -3.01 , but the estimated effect for DJNR-identified hostile offers [Host(WSJ)] and for offers with pre-bid events $[$ Host(Pre)] have a t-statistics of only -0.82 and -1.48 . An increase of M/B of 0.18 from its mean of 1.43 in this sample decreases the probability of an unnegotiated offer [Host(Uns)] by $1 \%$. For the composite hostility measure, the t-statistic of $\mathrm{M} / \mathrm{B}$ is -2.59 . This is consistent with the prior evidence of Mørck, Shleifer, and Vishny (1988) which could reflect poor management by target management. It could also reflect, however, a greater benefit from resistance to allow market participants to learn about the value of the assets of an undervalued target firm. ${ }^{5}$

ROE is negatively related to all of the measures of hostility, but only deals characterized as hostile by DJNR [Host(WSJ)], unnegotiated offers [Host(Uns)], and the composite hostility measure are reliably negative, with t-statistics of $-2.79,-2.11$, and -3.65 . An increase in ROE of 0.030 from its mean of 0.129 in this sample decreases the probability of an offer being characterized as hostile by DJNR [Host(WSJ)] by $1 \%$.

See, for example, Greene (1993, p. 639) for a description of this calculation.

I thank Paul Healy for suggesting this interpretation. 
Table 1 provides some evidence of shifts over time in the frequency of hostile offers, which appears to fall in 1990-96 to levels observed in the period 1976-79. In table 5, the dummy variables for 1980-84, 1985-89, and 1990-96 are negative for DJNR-identified offers [Host(WSJ)], with t-statistics of $-2.85,-1.11$, and -2.88 . Thus, for the DJNR-identified hostile offers, controlling for performance factors that influence the likelihood that an offer will be hostile, the 1975-79 period had the highest frequency of hostile offers.

In contrast, for hostile offers identified by pre-bid events [Host(Pre)], 1975-79 was the period of least hostility, controlling for performance factors. The dummy variables for 1980-84 and 1985-89 are positive for Host(Pre), with t-statistics of 3.30 and 6.07. The relatively low frequency of hostile offers based on pre-bid events from 1975-79 may only reflect the reporting practices of the Wall Street Journal, which did not seem to report 13D filings with the same frequency as DJNR has done since late 1979 .

Secular variation in the frequency of unnegotiated offers [Host(Uns)] is also significant. The pattern of intercept shifts is not as simple, however. Compared with the 1975-79 base period, unnegotiated offers were lower in 1980-84, higher in 1985-89, and lower in 1990-96, with t-statistics of $-1.05,3.59$, and -2.43 , respectively. A similar pattern occurs for the composite hostility variable, with t-statistics of $-0.94,4.14$, and -3.37 , respectively.

Thus, the results in table 5 are consistent with some of the earlier results of Mørck, Shleifer, and Vishny (1988), in that larger target firm size and higher M/B ratios lower the likelihood that a takeover bid will be hostile. In addition, there is weak evidence that target firms with higher ROE and sales growth have a lower likelihood of receiving a hostile offer. An additional important factor that can be seen (from the long time series available here) is that the frequency of hostile offers varies substantially over time for reasons that do not seem to be 
related to the performance of the target firms. This secular variation probably reflects changes in takeover technology that favor the relative bargaining positions of bidder and target firms, such as the availability of takeover-related financing and the nature of antitakeover devices, such as poison pills and state antitakeover laws. In terms of the explanatory power, the variables in table 5 that might reflect poor target management, M/B ratios and ROE, contribute little. The variables in table 5 that probably reflect the bargaining power of the target firm, such as firm size and the secular dummy variables, contribute the most explanatory power.

\section{Does hostility affect success, the premium, or the likelihood of an auction?}

From the perspective of the target firm, a hostile offer is one that it chooses to refuse publicly, often aggressively. If the goal is to avoid being acquired, this reaction should decrease the likelihood of a successful takeover. If the goal is to bargain for a better offer, this reaction should lead to a higher premium paid to target shareholders. Hard bargaining in pursuit of a higher premium could also lead to lower success rates, however, so the net of these effects must be used to judge whether target resistance benefits shareholders. One way to increase the expected premium is to initiate a multiple-bidder auction. Thus, it is also interesting to know whether auctions are any more likely when bids are hostile.

From the bidder's perspective, a hostile offer is necessary when a private negotiation is unlikely to succeed. It could be used to put pressure on entrenched managers by making target shareholders aware of their explicit options. It could also be used to move negotiations forward in a public arena where target managers' perceptions of the value of their company to other possible bidders can be resolved through a competitive process. This is analogous to litigation that proceeds to trial instead of settling through negotiation - the public process is necessary to resolve the differences of opinion between the bidder and the target. 


\subsection{Hostility and success rates}

Table 6 shows estimates of a probit model that predicts whether a takeover offer is successful. The dependent variable is a dummy variable that equals one when a bid leads to an acquisition of a target firm (even if a different bidder is the acquirer), and zero otherwise. The explanatory variables are the same performance variables used to predict hostility in table 5 . These models are estimated with and without the SDC measure of hostility, Host(SDC), because a substantial number of observations are lost by requiring SDC data. The estimates in the last three columns use the composite measure of hostility.

Of the four hostility variables, unnegotiated offers [Host(Uns)] have the largest adverse effect on success rates, with t-statistics of -8.34 and -9.62 . Given the other characteristics of the target firm and the other measures of hostility, success is $33.8 \%$ less likely when the bid is unnegotiated. Deals with pre-bid events [Host(Pre)] are less likely to be successful, with t-statistics of -1.85 and -5.08 . Deals identified as hostile by SDC [Host(SDC)] are more likely to be successful, given the other characteristics of the target firm and the other measures of hostility, with a t-statistic of 2.12. The composite hostility factor has a t-statistic of -8.98 .

Among the performance variables, targets with lower debt/equity ratios are more likely to be successfully taken over, with t-statistics of -1.77 and -3.23 . A decrease in D/E of 0.244 from its mean of 0.561 in this sample increases the probability that an offer will be successful by $1 \%$. Similarly, target firms with higher market/book ratios are more likely to be successfully taken over, with t-statistics of 1.68 and 2.40. An increase in M/B of 0.385 from its mean of 1.706 increases the probability that an offer will be successful by $1 \%$. The D/E effect is surprising since there is ample anecdotal evidence that targets can avoid takeover by adding debt (e.g., through a leveraged recapitalization). On the other hand, the attractiveness of the target to other 
potential bidders might be larger, all else equal, if the target has less debt. This conundrum shows the difficulty in modeling success rates, since I am really modeling mistakes. If the initial bidder was certain that a bid would fail, it is unlikely that the offer would be made.

Table 6 shows evidence consistent with figure 3 that success rates were lower from 1990-96 than in the earlier periods. The t-statistics for the 1990-96 dummy variable are -2.13 , -1.07 , and -1.24 , with $24.3 \%, 4.8 \%$, and $5.7 \%$ lower success probabilities, given the other variables in the model.

Thus, the estimates in table 6 show that unnegotiated offers are less likely to result in a successful takeover. Similarly, offers that are preceded by rumors or 13-D filings are less likely to result in a successful takeover. Whether this is due to entrenched target management or a tough bargaining stance cannot be inferred from this evidence alone.

\subsection{Hostility and pre-bid runups}

If hostility is a reflection of either the bidder's or the target's bargaining strategy, then the behavior of the target's stock price in the period before the first offer is announced is likely to be related to whether an offer is perceived to be hostile. For example, unnegotiated deals [Host(Uns)] are likely to be kept secret longer than negotiated transactions, so stock price runups should be lower. On the other hand, offers that are preceded by events that put the target firm in play [Host(Pre)] are likely to have larger runups as investors anticipate a corporate control transaction.

Table 7 shows estimates of a regression model that predicts the runup in the target's stock price in the 63 trading days before successful and unsuccessful takeover bids adjusted for market movements. These models are estimated with and without the SDC measure of hostility, Host(SDC). The estimates in the last two columns use the composite measure of hostility. 
The performance variables used to predict hostility in table 5 (ROE, Sales Growth, Liquidity, D/E, M/B, P/E, and Size) are not reliably related to the runup, except that target firms with less liquidity seem to experience lower runups (t-statistics of $-2.06,-2.55$, and -2.65 ). As noted by Schwert (1996), average runups were higher from 1975-79 than in later periods, as shown by the negative estimates for the coefficients of the time period dummy variables (t-statistics of $-4.45,-6.00$, and -6.66 in the larger sample omitting SDC).

Given the other variables in the model, deals identified as hostile by DJNR [Host(WSJ)] do not have reliably different runups. Deals identified as hostile by SDC [Host(SDC)] have runups that are $6.5 \%$ higher on average (t-statistic of 2.89). As predicted, however, unnegotiated deals [Host(Uns)] have lower runups by $9.5 \%$ or $5.2 \%$ on average, with t-statistics of -4.40 and -3.75. To the extent that unnegotiated deals can be kept secret longer, the lower runups are not surprising. Deals with pre-bid events that put the target in play [Host(Pre)] have runups that are $8.1 \%$ or $5.5 \%$ higher on average, with t-statistics of 4.53 and 4.13 . This result is also expected since the pre-bid events reveal information to the public as part of the bidder's or the target's bargaining strategy.

Because the effects of pre-bid publicity and unsolicited offers are opposite, the composite measure of hostility is not related to the size of the pre-bid runup, with a t-statistic of -1.53.

\subsection{Hostility and takeover premiums}

Table 8 shows estimates of a regression model that predicts the premium received by target shareholders in successful and unsuccessful takeover bids, where the premium is measured as the cumulative abnormal return to the target firm's stock for trading days $(-63,126)$ relative to the date of the first bid (the sum of the runup and the markup). The performance variables used to predict hostility in table 5 (ROE, Sales Growth, Liquidity, D/E, M/B, P/E, and Size) are 
included along with the five measures of hostility, and dummy variables to allow for secular variation in 1980-84, 1985-89, or 1990-96.

Columns (3), (7), and (11) show regressions that include four deal characteristics (whether the target firm has a poison pill, Pill; whether another bidder enters the competition for the target firm, Auction; whether the payment to target shareholders is all in the form of cash, Cash; and whether the deal is a tender offer, Tender Offer). Unlike the performance and hostility variables, these deal characteristics are generally not known before the first bid is announced, and some are not known until the outcome of the deal has been determined.

There is weak evidence that takeover premiums are negatively related to target firm size, with t-statistics between -1.20 and -2.82 across specifications. In column (1), a decrease of $\$ 57$ million in equity capitalization, which averages $\$ 219$ million in this sample, increases the premium received by the target by $1 \%$. The performance variables are not reliably related to takeover premiums, which is consistent with the results of Comment and Schwert (1995).

$D J N R$-identified hostile offers [Host(WSJ)] are not associated with differential premiums, except in the model in column (5), which excludes the SDC measure of hostility and the deal characteristic variables, with a t-statistic of 2.41. In column (5), the average premium is higher by $9.0 \%$ in $D J N R$-identified hostile offers.

SDC-identified hostile offers are associated with higher average premiums of $15.1 \%$ in column (1), which excludes the deal characteristics. Unnegotiated offers [Host(Uns)] are associated with premiums that are reliably lower than average in columns (1), (3), and (7), but not in column (5), which excludes the SDC measure of hostility and the deal characteristics. This reflects the lower success rates associated with unsolicited offers seen in table 6 . 
The dummy variables for 1980-84, 1985-89, and 1990-96 are not reliably different from zero in all specifications. Auctions, cash offers, and tender offers all lead to higher than average premiums, with coefficient estimates between $8.2 \%$ and $15.1 \%$ and t-statistics between 2.51 and 6.09. Given these other characteristics, there is no reliable association between poison pills and takeover premiums (although the estimates are positive).

Thus, the evidence on premiums received by target shareholders is mixed. The lower success rates for unnegotiated offers [Host(Uns)] shown in table 6 lead to slightly lower premiums averaged across both successful and unsuccessful transactions. On the other hand, deals that are characterized as hostile by $D J N R$ or SDC have slightly higher average premiums. These results are consistent with the view that hostility is the outcome of aggressive bargaining by target managers.

\subsection{Hostility and auctions}

If hostility is a result of target resistance that is intended to seek a better deal, the frequency of multiple bidder auctions should be higher when an offer is hostile. To the extent that target firms simply want to avoid being taken over, there would be no advantage to seeking additional bidders.

Table 9 shows estimates of a probit model that predicts whether more than one bidder is competing for a given target firm. The performance variables used to predict hostility in table 5 (ROE, Sales Growth, Liquidity, D/E, M/B, P/E, and Size) are included along with the measures of hostility, and dummy variables to allow for secular variation in 1980-84, 1985-89, or 1990-96. These models are estimated with and without the SDC measure of hostility, Host(SDC), because a substantial number of observations are lost by requiring SDC data. The estimates in the last three columns use the composite measure of hostility. 
All of the measures of hostility have a reliably higher probability of leading to an auction. In columns (1)-(3), given the other characteristics of the target firm, an auction is $15.5 \%$ more likely when the bid is identified as hostile by SDC (t-statistic of 3.86). An auction is 12.7\% more likely when the bid is unnegotiated (t-statistic of 3.41). An auction is $9.9 \%$ more likely when the bid is preceded by takeover-related events ( $\mathrm{t}$-statistic of 2.95).

Given the other definitions of hostility, the deals identified as hostile by DJNR are not related to the likelihood that an auction will occur. However, when the SDC hostility variable is excluded in columns (4)-(6), the DJNR measure of hostility [Host(WSJ)] becomes significant, predicting a $13.6 \%$ greater chance of an auction (with a t-statistic of 3.83). When the composite hostility factor is used in columns (7)-(9), this variable is strongly related to the likelihood of an auction, with a t-statistic of 9.44 .

None of the performance variables or the pre-bid runup is a reliable predictor of whether an auction will occur.

Thus, there is strong evidence that auctions are related to hostility. Of course, the causality could run in either direction. Hostile bids could cause target managers to seek out competing "white knight" bidders who would be less threatening. Alternatively, takeover rumors $[$ Host(Pre)] could reflect the activity of a different bidder simultaneous with the actions of the hostile bidder. Likewise, the existence of a competitor could cause a bidder to pursue an unnegotiated offer [Host(Uns)] to gain bargaining power by publicizing its offer to target shareholders, perhaps giving it a first-mover advantage.

\subsection{Hostility and bidder returns}

The decision to make a hostile bid is a strategy choice for the bidder firm (see Herzel and Shepro (1990), Chapter 13, for example). It presumably reflects a judgment that a favorable 
outcome is more likely from the hostile bid than from private negotiations with the target firm, and that a hostile bid is better than making no bid at all. Alternative views of this process assume less rational decision-making by bidders. For example, Roll's (1986) hubris hypothesis asserts that bidders pay too much for target firms in the interest of winning a competitive takeover contest. From the perspective of target shareholders, overpayment by bidders is a desirable outcome.

The difference between public and private bidders is an interesting question. To the extent that agency costs are larger in public firms, the likelihood of hubris or empire-building behavior is larger. On the other hand, public firms are likely to be larger because of their access to capital markets. Table 10 shows the average values of several variables that might be related to the bidder's stock price when takeover bids are announced and the difference between the average for the full sample of takeover bids (from table 1) and the subset of 1,286 bids made by public firms, along with heteroskedasticity-consistent t-statistics (in columns (2) and (3)).

Among the hostility variables, the deals identified as hostile by $D J N R$ occur more frequently in the sample with public bidders (t-statistic of 1.86). As mentioned before, this is not surprising since $D J N R$ devotes more coverage to large and more prominent firms. On the other hand, deals identified as hostile by SDC occur less frequently in the sample with public bidders (t-statistic of -2.64). Unnegotiated offers [Host(Uns)] and offers following pre-bid events that put the target in play [Host(Pre)] are much less frequent (t-statistics of --12.29 and -4.50) for public firms. This could reflect a reluctance of public firms to act aggressively toward other public firms, perhaps due to a cultural taboo among executives of public firms. ${ }^{6}$ It could also reflect the differences in bargaining power that public firms have due to their generally larger

\footnotetext{
6 For example, many people have noted that hostile offers are rare in Europe and Japan and attribute that difference to the cultures of these countries (i.e., accepted business practices).
} 
size. Smaller private firms could value the publicity a hostile offer creates as a way of putting pressure on the target firm to consider their offer. The composite hostility measure, Host(Factor), is reliably smaller in the sample of deals with public bidders (t-statistic of -7.46).

Public firms make offers for targets that have poison pills less frequently than private firms (t-statistic of -3.30) and their offers lead to successful takeovers more frequently (t-statistic of 4.38). Public firms use cash less frequently and equity more frequently (t-statistics of -18.33 and 18.09) than private firms, which is not surprising since the public firms have equity that is traded in a liquid secondary market (some of the bidders have stock that is listed on foreign exchanges, so the distinction between "public" and "private" is not completely descriptive).

The average runup, markup, and premium for the target firm's stock price are not reliably different for bids made by public firms. Public firms pursue target firms that are larger on average than the average target size in table 1 ( $\$ 168.0$ million versus $\$ 117.5$ million, with a tstatistic of 4.98).

Table 10 also shows the effects of sample selection bias when all of the variables in table 10 are required to be available to estimate the regression models in table 11 . These models are estimated with and without the SDC measure of hostility, Host(SDC). There are 726 deals with complete data and 1,253 deals with complete data if the SDC hostility variable is omitted. The general tendencies shown in columns (2) and (3) are repeated in the regression samples in columns (4)-(7). The results in table 10 suggest that bids made by public firms could be systematically different from those made by private or foreign bidders.

Table 11 analyzes the returns to the stocks of publicly traded bidder firms around the time of bid. The dependent variable is the cumulative abnormal return for days $(-63,126)$ relative to the first bid, analogous to the premium calculated for the target firm's stock price. 
Many papers have shown that bidders tend to have had unusual positive stock price performance in the year before they bid, which causes abnormal stock returns measured around the time of the bid to drift downward. This is shown in figure 4 where three measures of abnormal stock price performance are plotted. The solid line represents the cumulative prediction errors from the market model estimated using the CRSP value-weighted portfolio for days $(-316,-64)$, which is the method used to calculate target firms' abnormal performance in this paper. The second method (shown by $\mathbf{X}$ in figure 4) is to subtract the CRSP value-weighted return from the bidder's return, the market-adjusted return, which is equivalent to constraining the market model estimates in (2) so that $\alpha_{i}=0$ and $\beta_{i}=1$. The third method (shown by $\mathbf{O}$ in figure 4) is to subtract the prediction from the estimated market model regression, but to constrain the intercept to equal zero, $\varepsilon_{i t}=R_{i t}-\beta_{i} R_{m t}$ [Schwert (1996) uses this technique to analyze bidders' returns around takeover announcements]. Figure 4 shows that, at least on average, the problem with using the historical market model estimates as a benchmark for normal performance for bidders is caused by positive intercept estimates that reflect unusually good prior performance that does not continue during the event period. To correct for this downward drift in average bidder returns, I use the third method for the regressions in table 11.

The regressors in table 11 include the four measures of hostility, the sizes (log of equity capitalization) of the target and bidder firms, the runup and markup experienced by the target firm's stock price, and dummy variables for the 1980-84, 1985-89, and 1990-96 periods. Columns (3) and (4) show results for a regression that also includes deal characteristics, some of which are not generally known at the time of the first bid, including whether the target has a poison pill, whether a multiple bidder auction occurs, whether cash is the only form of 
compensation offered to target shareholders, and whether the target firm is successfully taken over by some bidder.

The only measure of hostility that seems to explain bidder stock price behavior are deals where the target is in play before the first bid [Host(Pre)], with abnormal returns that are $4.7 \%$ lower in column (1) (t-statistic of -2.12). SDC-identified hostile deals [Host(SDC)], unnegotiated deals [Host(Uns)], and deals identified as hostile by DJNR [Host(WSJ)], do not have reliably different bidder returns. The composite hostility measure, Host(Factor), used in columns (9)-(12) is also negatively related to bidder returns.

Larger bidder firms are associated with higher bidder returns. This is inconsistent with Roll's hubris hypothesis to the extent that large bidder firms are likely to have more diffuse ownership structures that allow management to pursue non-value-maximizing takeover strategies.

On the other hand, bidder returns are positively related with both the runup and the markup for the target firm, which is inconsistent with the notion that low bidder returns are explained by overpayment for target stock, with t-statistics of 1.68 and 2.64 . The $1980-84,1985-$ 89, and 1990-96 dummy variable coefficient estimates are all positive, with t-statistics of 2.30, 1.83 , and 1.12, indicating that bidder returns were lower in 1975-79, given the other variables in the model.

Among the deal characteristics in columns (3) and (4), cash offers are associated with higher than average bidder returns, with a t-statistic of 2.46. The other deal variables do not add much explanatory power, given the other variables in the regression.

The estimates in columns (5)-(8) omit the SDC measure of hostility and therefore increase the sample size substantially. The main difference in results in these samples is that the 
time period dummy variables are negative, implying that bidder returns were lower in 1975-79, given the other variables in the model. Also, in this sample it seems that bidders involved in auctions have returns that are $8.4 \%$ lower, with a t-statistic of -3.28 . This is not surprising, since the occurrence of an auction is likely to be bad news for the first bidder.

Regressions like those in table 11 could fail to explain much of the cross-sectional variation in bidder's stock returns because many of the explanatory variables are choice or strategy variables for the bidder. If the bidder is selecting the value-maximizing strategy at each opportunity, there may be no reliable relation between realized stock returns and the choices that were made. Only in cases where the choices are not solely determined by the bidder, or there are unforeseen surprises, or if the bidder is not pursuing a value-maximizing strategy, would we expect to see predictable relations between bidder returns and the chosen strategies.

Nevertheless, the lack of a strong relation between hostility and bidders' stock returns suggests that the choice of whether to pursue a hostile offer is ambiguous - it depends on the facts and circumstances of each case. Moreover, the choice made by the bidder is strongly affected by the perceived attitude of the target firm.

\section{Summary and conclusions}

Taking all of the evidence together, there is support for both target management entrenchment and for bargaining strategy as explanations for the perception of hostility in tender offers. This is not surprising since these hypotheses are not mutually exclusive. Nevertheless, on balance, hostility in takeover negotiations seems to be most strongly related to strategic bargaining.

One contribution of this paper is to study a long time series of takeover offers. I find that there is much secular variation in the frequency of hostile offers that probably reflects changes in 
takeover technology which favor the relative bargaining positions of the bidder and target firms, such as the availability of takeover-related financing and the nature of private and public antitakeover devices. When trying to explain the occurrence of hostility in table 5, the variables that are most likely to reflect poor target management, $\mathrm{M} / \mathrm{B}$ ratios and $\mathrm{ROE}$, contribute little explanatory power. The variables that probably reflect the bargaining power of the target firm, such as firm size and the secular dummy variables, contribute the most explanatory power in table 5 .

The bargaining hypothesis predicts that target managers resist hostile offers to improve the terms of a takeover offer. The entrenchment hypothesis predicts that target managers resist hostile offers to avoid being taken over. Unnegotiated offers [Host(Uns)] have lower success rates in table 6. This explains the slightly lower premiums for unnegotiated offers averaged across both successful and unsuccessful transactions in table 8 . On the other hand, deals that are characterized as hostile by DJNR or SDC have slightly higher average premiums. These results are consistent with the view that hostility is the outcome of aggressive bargaining by target managers.

There is strong evidence that auctions are related to hostility in table 9. This could reflect target managers seeking out "white knight" bidders who would be less threatening. On the other hand, potential competition could lead a bidder to pursue an unnegotiated offer [Host(Uns)] to gain bargaining power by publicizing its offer to target shareholders, perhaps giving it a first-mover advantage. I am inclined to interpret hostility related to auctions as evidence of bargaining strategy rather than entrenchment.

Finally, there is evidence that offers identified as hostile by pre-bid events [Host(Pre)] are associated with reductions in the bidder's stock price. Other measures of hostility are not related 
to the bidder's stock returns. I conclude that bidders choose to use hostile offers rationally. The higher premiums paid to target shareholders and the lower success rates associated with unnegotiated offers do not result in lower bidder stock returns in most cases.

In summary, most of the characteristics of takeover offers that are related to hostility seem to reflect strategic choices made by the bidder or the target firm to maximize their respective gains from a potential transaction. There are probably some transactions in this large dataset that exhibit non-value-maximizing target management entrenchment, but they are dominated by cases where strategic bargaining is the motivation for hostility in the sample averages and regression estimates. 


\section{References}

Chan, Louis K. C., N. Jegadeesh, and Josef Lakonishok, 1995, Evaluating the performance of value versus glamour stocks: The impact of selection bias, Journal of Financial Economics 38, 269-296.

Comment, Robert and G. William Schwert, 1995, Poison or placebo? Evidence on the deterrence and wealth effects of modern antitakeover measures, Journal of Financial Economics 39, 3-43.

Greene, William H., 1993, Econometric analysis, 2nd ed. (Macmillan, New York).

Harford, Jarrad, 1999, Corporate cash reserves and acquisitions, Journal of Finance 54, forthcoming.

Hasbrouck, Joel, 1985, The characteristics of takeover targets, Journal of Banking and Finance 9, 351-362.

Healy Paul M., Krishna G. Palepu, and Richard S. Ruback, 1992, Does corporate performance improve after mergers? Journal of Financial Economics 31, 135-176.

Herzel, Leo and Richard W. Shepro, 1990, Bidders and targets: Mergers and acquisitions in the U.S. (Blackwell, Cambridge, MA).

Jensen, Michael C., 1986, Agency costs of free cash flow, corporate finance, and takeovers, American Economic Review 76, 323-329.

Lang, Larry H. P., René M. Stulz and Ralph A. Walkling, 1989, Managerial performance, Tobin's Q, and the gains from successful tender offers, Journal of Financial Economics $24,137-154$.

Manne, Henry G., 1965, Mergers and the market for corporate control, Journal of Political Economy 73, 110-120.

Mikkelson, Wayne H. and M. Megan Partch, 1989, Managers' voting rights and corporate control, Journal of Financial Economics 25, 263-290.

Mitchell, Mark L. and Jeffry M. Netter, 1989, Triggering the 1987 stock market crash: Antitakeover provisions in the proposed House Ways and Means tax bill?, Journal of Financial Economics 24, 37-68.

Mørck, Randall, Andrei Shleifer, and Robert W. Vishny, 1988, Characteristics of targets of hostile and friendly takeovers, in: Alan J. Auerbach, ed., Corporate takeovers: Causes and consequences (National Bureau of Economic Research, Chicago, IL) 101-129.

Mørck, Randall, Andrei Shleifer, and Robert W. Vishny, 1989, Alternative mechanisms for corporate control, American Economic Review 89, 842-852. 
Opler, Tim, Lee Pinkowitz, René M. Stulz, and Rohan Williamson, 1999, The determinants and implications of corporate holdings of liquid assets, Journal of Financial Economics 52, forthcoming.

Palepu, Krishna G., 1986, Predicting takeover targets: A methodological and empirical analysis, Journal of Accounting and Economics 8, 3-35.

Roll, Richard, 1986, The hubris hypothesis of corporate takeovers, Journal of Business 59, 197216.

Schwert, G. William, 1996, Markup pricing in mergers and acquisitions, Journal of Financial Economics 41, 153-192.

Shivdasani, Anil, 1993, Board composition, ownership structure, and hostile takeovers, Journal of Accounting and Economics 16, 167-198.

Sridharan, Uma V. and Marc R. Reinganum, 1995, Determinants of the choice of the hostile takeover mechanism: An empirical analysis of tender offers and proxy contests, Financial Management 24, 57-67.

White, Halbert, 1980, A heteroskedasticity-consistent covariance matrix estimator and a direct test for heteroskedasticity, Econometrica 48, 817-838. 


\section{Table 1}

Summary statistics for takeover characteristics and measures of hostility, 1975-96

Average values of prior accounting and stock market performance, and the proportions of firms in various takeover categories for successful and unsuccessful takeover bids for exchange-listed target firms, 1975-96. The estimates in columns (4) to (7) are differences in means from the full sample of 2,346 cases, with a t-statistic testing whether the difference is reliably different from zero using White's (1980) heteroskedasticity-consistent standard errors.

Host(WSJ) is based on descriptions in the Wall Street Journal Index or Dow Jones News Retrieval (DJNR), Host(SDC) is based on whether the target firm resisted an unsolicited offer as determined by the Securities Data Corporation (SDC), Host(Uns) is based on whether the initial or winning bid is unsolicited, and Host(Pre) is based on whether the target firm is in play (someone has filed a 13D form with the S.E.C. showing an accumulation of shares within the past 12 months) or the subject of a takeover rumor reported in DJNR. Host(Factor) is the first factor or principal component from the set of three hostility variables with complete data [Host(WSJ), Host(Uns), and Host(Pre)]. Deal characteristics show the proportions of the full sample in which the target firm has a poison pill in place (Pill), whether there is a multiple bidder auction (Auction), whether the target firm is taken over without more than a one year hiatus between bids (Success), whether there is an all-cash payment to target shareholders (Cash), whether there is an all-equity payment to target shareholders (Equity), whether the deal is a tender offer (Tender Offer), and whether the bidder is an exchange-listed company (Public Bidder). Performance statistics show how the target firm was performing before the takeover bid. ROE is earnings divided by average stockholder's (book) equity and Sales Growth is the growth in sales over the fiscal year before the first bid. Liquidity is the ratio of net liquid assets to total assets, D/E is the long-term debt to book equity, M/B is the ratio of market to book value of stockholder's equity, $\mathrm{P} / \mathrm{E}$ is the ratio of stock price to the earnings for the last fiscal year, and Size is the logarithm of the market value of common stock, all measured at the end of the fiscal year before the first bid. Target stock price behavior shows the cumulative abnormal stock returns measured relative to a CRSP value-weighted market model regression estimated using a year of prior data for several periods. Runup is the cumulative abnormal return to the target firm's stock for trading days $(-63,-1)$ before the first bid, Markup is the cumulative abnormal return for trading days $(0,126)$, and Premium is the cumulative abnormal return for trading days $(-63,126)$ [market model estimates from days $(-316,-64)]$.

\begin{tabular}{|c|c|c|c|c|c|c|c|c|c|c|c|}
\hline & (1) & (2) & (3) & & & \multirow{2}{*}{\multicolumn{2}{|c|}{$\underline{\text { Host(SDC) vs. Full }}$}} & \multirow{2}{*}{\multicolumn{2}{|c|}{$\begin{array}{c}(6) \\
\text { Host(Uns) vs. Full }\end{array}$}} & \multirow{2}{*}{\multicolumn{2}{|c|}{$\begin{array}{c}(7) \\
\text { Host(Pre) vs. Full }\end{array}$}} \\
\hline & \multicolumn{3}{|c|}{$\underline{\text { Full Sample }(\mathrm{N}=2,346)}$} & \multicolumn{2}{|c|}{$\underline{\text { Host(WSJ) vs. Full }}$} & & & & & & \\
\hline & Cases & Mean & Std Error & Diff & T-statistic & Diff & T-statistic & Diff & T-statistic & Diff & T-statistic \\
\hline \multicolumn{12}{|c|}{ Measures of Hostility } \\
\hline Host(WSJ) & 174 & 0.074 & 0.005 & & & 0.342 & 12.32 & 0.144 & 12.04 & 0.058 & 5.16 \\
\hline Host(SDC) & 300 & 0.216 & 0.011 & 0.746 & 25.19 & & & 0.378 & 17.73 & 0.140 & 6.45 \\
\hline Host(Uns) & 990 & 0.422 & 0.010 & 0.513 & 20.23 & 0.552 & 23.27 & & & 0.143 & 7.01 \\
\hline Host(Pre) & 1,043 & 0.445 & 0.010 & 0.209 & 5.50 & 0.207 & 6.64 & 0.145 & 7.02 & & \\
\hline Host(Factor) & & 0.246 & 0.005 & 0.706 & 69.26 & 0.376 & 20.34 & 0.389 & 50.64 & 0.267 & 28.88 \\
\hline
\end{tabular}




\begin{tabular}{|c|c|c|c|c|c|c|c|c|c|c|c|}
\hline & $(1)$ & & (3) & & & \multirow{2}{*}{\multicolumn{2}{|c|}{$\begin{array}{c}(5) \\
\underline{\text { Host(SDC) vs. Full }}\end{array}$}} & \multirow{2}{*}{\multicolumn{2}{|c|}{$\begin{array}{c}(6) \\
\underline{\text { Host(Uns) vs. Full }}\end{array}$}} & \multirow{2}{*}{\multicolumn{2}{|c|}{$\begin{array}{c}(7) \\
\text { Host(Pre) vs. Full }\end{array}$}} \\
\hline & \multicolumn{3}{|c|}{ Full Sample $(\mathrm{N}=2,346)$} & \multicolumn{2}{|c|}{$\underline{\text { Host(WSJ) vs. Full }}$} & & & & & & \\
\hline & Cases & Mean & Std Error & Diff & T-statistic & Diff & T-statistic & Diff & T-statistic & Diff & T-statistic \\
\hline \multicolumn{12}{|c|}{ Deal Characteristics } \\
\hline Pill & 218 & 0.093 & 0.006 & 0.229 & 6.47 & 0.267 & 9.25 & 0.128 & 9.84 & 0.131 & 10.44 \\
\hline Auction & 454 & 0.194 & 0.008 & 0.331 & 8.54 & 0.316 & 10.27 & 0.254 & 15.05 & 0.126 & 7.59 \\
\hline Success & 1,751 & 0.746 & 0.009 & -0.074 & -2.01 & -0.116 & -3.86 & -0.276 & -15.14 & -0.134 & -7.35 \\
\hline Cash & 1,363 & 0.581 & 0.010 & 0.179 & 5.18 & 0.208 & 7.07 & 0.241 & 12.23 & 0.035 & 1.69 \\
\hline Equity & 556 & 0.237 & 0.009 & -0.169 & -7.48 & -0.186 & -8.52 & -0.246 & -15.47 & -0.119 & -6.97 \\
\hline Tender Offer & 763 & 0.325 & 0.010 & 0.431 & 12.22 & 0.313 & 9.96 & 0.166 & 8.45 & 0.065 & 3.34 \\
\hline $\begin{array}{l}\text { Public Bidder } \\
\text { (First) }\end{array}$ & 1,426 & 0.608 & 0.010 & 0.070 & 1.88 & -0.088 & -2.73 & -0.251 & -12.53 & -0.116 & -5.71 \\
\hline $\begin{array}{l}\text { Public Bidder } \\
\text { (Winner) }\end{array}$ & 1,174 & 0.500 & 0.010 & -0.031 & -0.80 & -0.117 & -3.61 & -0.291 & -14.59 & -0.133 & -6.45 \\
\hline \multicolumn{12}{|c|}{$\underline{\text { Performance Statistics }}$} \\
\hline ROE & 1,631 & 0.090 & 0.003 & 0.005 & 0.59 & 0.015 & 1.69 & -0.024 & -3.66 & -0.009 & -1.34 \\
\hline Sales Growth & 1,630 & 0.078 & 0.005 & -0.040 & -2.75 & -0.020 & -1.42 & -0.035 & -3.49 & -0.021 & -2.08 \\
\hline Liquidity & 1,468 & 0.247 & 0.006 & -0.026 & -1.32 & -0.003 & -0.21 & 0.004 & 0.39 & -0.029 & -2.60 \\
\hline $\mathrm{D} / \mathrm{E}$ & 1,622 & 0.999 & 0.102 & -0.507 & -4.09 & -0.587 & -2.87 & -0.120 & -0.56 & 0.107 & 0.52 \\
\hline $\mathrm{M} / \mathrm{B}$ & 1,612 & 1.670 & 0.093 & -0.465 & -3.72 & -0.672 & -3.95 & -0.173 & -0.83 & -0.221 & -1.22 \\
\hline $\mathrm{P} / \mathrm{E}$ & 1,336 & 13.674 & 0.326 & -1.929 & -2.55 & -1.667 & -1.89 & -0.941 & -1.43 & 0.210 & 0.32 \\
\hline Size & 2,306 & 11.512 & 0.036 & 1.468 & 11.81 & 0.929 & 9.22 & 0.189 & 2.62 & 0.573 & 8.07 \\
\hline \multicolumn{12}{|c|}{$\underline{\text { Target Stock Price Behavior }}$} \\
\hline Runup & 2,296 & 0.124 & 0.005 & -0.007 & -0.52 & 0.015 & 1.09 & -0.022 & -2.17 & 0.047 & 4.56 \\
\hline Markup & 2,296 & 0.096 & 0.007 & 0.122 & 5.40 & 0.051 & 2.36 & 0.023 & 1.63 & -0.081 & -6.02 \\
\hline Premium & 2,296 & 0.220 & 0.009 & 0.115 & 4.46 & 0.067 & 2.53 & 0.000 & 0.01 & -0.034 & -1.89 \\
\hline
\end{tabular}


Table 2

Correlations among different measures of hostility, 1975-96

Host(WSJ) is based on descriptions in the Wall Street Journal Index or Dow Jones News Retrieval (DJNR). Host(SDC) is based on whether the target firm resisted an unsolicited offer as determined by the Securities Data Corporation (SDC). Host(Uns) is based on whether the initial or winning bid is unsolicited. Host(Pre) is based on whether the target firm is in play (someone has filed a 13D form with the S.E.C. showing an accumulation of shares within the past 12 months) or the subject of a takeover rumor reported in DJNR. Asymptotic standard errors for the correlation coefficients are between 0.021 and 0.027 under the hypothesis of no correlation. Host(Factor) is the first factor or principal component from the set of three hostility variables with complete data [Host(WSJ), Host(Uns), and Host(Pre)].

\begin{tabular}{lcccc}
\hline & Host(SDC) & Host(Uns) & Host(Pre) & Host(Factor) \\
Host(WSJ) & 0.502 & 0.272 & 0.152 & 0.737 \\
Host(SDC) & & 0.457 & 0.181 & 0.578 \\
Host(Uns) & & 0.208 & 0.753 \\
Host(Pre) & & & 0.560 \\
\hline
\end{tabular}

Cross-Tabulations Among Selected Hostility Measures

These cross-tabulations show the frequency and types of disagreements among the four hostility measures.

\begin{tabular}{lcccc}
\hline & Host $($ SDC $)=1$ & Host $($ SDC $)=0$ & Host $($ Uns $)=1$ & Host $($ Uns $)=0$ \\
Host $($ WSJ $)=1$ & 106 & 12 & 156 & 18 \\
Host $($ WSJ $)=0$ & 194 & 1077 & 834 & 1338 \\
& Host $($ Uns $)=1$ & Host $($ Uns $)=0$ & Host $($ Pre $)=1$ & Host $($ Pre $)=0$ \\
Host $($ SDC $)=1$ & 263 & 37 & 198 & 102 \\
Host $($ SDC $)=0$ & 354 & 735 & 493 & 596 \\
& Host $($ WSJ $)=1$ & Host $($ WSJ $)=0$ & Host $($ Uns $)=1$ & Host $($ Uns $)=0$ \\
Host $($ Pre $)=1$ & 111 & 932 & 523 & 520 \\
Host $($ Pre $)=0$ & 63 & 1240 & 467 & 836 \\
\hline
\end{tabular}




\section{Table 3}

Frequency of hostile transactions by year for different measures of hostility, 1975-96

The proportions of successful and unsuccessful takeover bids for exchange-listed target firms for each year from 1975-96. The estimates in columns (4) - (7) are differences in means from the full sample of 2,346 cases, with a t-statistic testing whether the difference is reliably different from zero using White's (1980) heteroskedasticity-consistent standard errors. Host(WSJ) is based on descriptions in the Wall Street Journal Index or Dow Jones News Retrieval, Host(SDC) is based on whether the target firm resisted an unsolicited offer as determined by the Securities Data Corporation (SDC), Host(Uns) is based on whether the initial or winning bid is unsolicited, and Host(Pre) is based on whether the target firm is in play (someone has filed a 13D form with the S.E.C. showing an accumulation of shares within the past 12 months) or the subject of a takeover rumor reported in DJNR.

\begin{tabular}{|c|c|c|c|c|c|c|c|c|c|c|c|}
\hline \multirow[b]{2}{*}{ Year } & \multirow{2}{*}{$\begin{array}{c}\text { (1) } \\
\text { Cases } \\
\end{array}$} & \multirow{2}{*}{$\begin{array}{l}\text { (2) } \\
\text { Ful } \\
\text { Mean }\end{array}$} & \multirow{2}{*}{$\begin{array}{l}\text { (3) } \\
\text { mple } \\
\text { Std Error }\end{array}$} & \multicolumn{2}{|c|}{$\begin{array}{c}\text { (4) } \\
\text { Host(WSJ) vs. } \\
\underline{\text { Full Sample }}\end{array}$} & \multicolumn{2}{|c|}{$\begin{array}{c}(5) \\
\frac{\text { Host(SDC) vs. }}{\underline{\text { Full Sample }}}\end{array}$} & \multicolumn{2}{|c|}{$\begin{array}{c}\text { (6) } \\
\underline{\text { Host(Uns) vs. }} \\
\underline{\text { Full Sample }}\end{array}$} & \multicolumn{2}{|c|}{$\begin{array}{c}(7) \\
\text { Host(Pre) vs. } \\
\underline{\text { Full Sample }}\end{array}$} \\
\hline & & & & Diff & T-statistic & Diff & T-statistic & Diff & T-statistic & Diff & T-statistic \\
\hline 1975 & 49 & 0.021 & 0.003 & -0.010 & -1.17 & & & -0.010 & -1.72 & -0.022 & -3.96 \\
\hline 1976 & 66 & 0.028 & 0.003 & -0.006 & -0.47 & & & 0.000 & 0.04 & -0.025 & -3.80 \\
\hline 1977 & 116 & 0.049 & 0.004 & -0.016 & -1.11 & -0.001 & -1.00 & 0.007 & 0.77 & -0.042 & -4.96 \\
\hline 1978 & 113 & 0.048 & 0.004 & 0.010 & 0.55 & 0.009 & 1.19 & -0.010 & -1.13 & -0.014 & -1.62 \\
\hline 1979 & 134 & 0.057 & 0.005 & 0.013 & 0.65 & -0.001 & -0.32 & -0.008 & -0.83 & -0.015 & -1.56 \\
\hline 1980 & 124 & 0.053 & 0.005 & -0.026 & -1.92 & -0.014 & -2.73 & -0.022 & -2.38 & -0.014 & -1.53 \\
\hline 1981 & 96 & 0.041 & 0.004 & -0.007 & -0.48 & 0.009 & 0.75 & -0.001 & -0.11 & 0.002 & 0.28 \\
\hline 1982 & 98 & 0.042 & 0.004 & -0.002 & -0.11 & 0.004 & 0.36 & -0.009 & -1.14 & 0.001 & 0.09 \\
\hline 1983 & 97 & 0.041 & 0.004 & -0.020 & -1.63 & -0.002 & -0.15 & -0.010 & -1.27 & 0.010 & 1.21 \\
\hline 1984 & 126 & 0.054 & 0.005 & -0.008 & -0.50 & -0.008 & -0.51 & 0.017 & 1.78 & 0.016 & 1.63 \\
\hline 1985 & 137 & 0.058 & 0.005 & 0.049 & 2.06 & 0.034 & 1.71 & 0.004 & 0.39 & 0.026 & 2.62 \\
\hline 1986 & 186 & 0.079 & 0.006 & 0.020 & 0.86 & 0.030 & 1.38 & 0.052 & 4.39 & 0.028 & 2.47 \\
\hline 1987 & 160 & 0.068 & 0.005 & 0.019 & 0.89 & 0.039 & 1.80 & 0.048 & 4.36 & 0.038 & 3.52 \\
\hline 1988 & 211 & 0.090 & 0.006 & 0.058 & 2.13 & 0.063 & 2.62 & 0.068 & 5.45 & 0.078 & 6.35 \\
\hline 1989 & 146 & 0.062 & 0.005 & 0.013 & 0.65 & -0.020 & -1.17 & 0.023 & 2.26 & 0.055 & 5.31 \\
\hline 1990 & 60 & 0.026 & 0.003 & -0.003 & -0.24 & -0.021 & -2.11 & -0.004 & -0.62 & 0.009 & 1.38 \\
\hline 1991 & 55 & 0.023 & 0.003 & -0.019 & -2.88 & -0.027 & -3.30 & -0.006 & -0.90 & -0.006 & -0.96 \\
\hline 1992 & 44 & 0.019 & 0.003 & -0.014 & -2.17 & -0.016 & -1.92 & -0.018 & -3.54 & -0.018 & -3.43 \\
\hline 1993 & 60 & 0.026 & 0.003 & -0.015 & -1.73 & -0.035 & -4.11 & -0.027 & -4.44 & -0.012 & -1.80 \\
\hline 1994 & 71 & 0.030 & 0.004 & 0.005 & 0.32 & -0.020 & -1.65 & -0.026 & -3.93 & -0.027 & -3.98 \\
\hline 1995 & 83 & 0.035 & 0.004 & -0.001 & -0.07 & 0.015 & 0.95 & -0.021 & -2.86 & -0.017 & -2.29 \\
\hline 1996 & 114 & 0.049 & 0.004 & -0.040 & -4.28 & -0.037 & -2.61 & -0.047 & -5.74 & -0.051 & -6.13 \\
\hline
\end{tabular}




\section{Table 4}

\section{Tests for sample selection bias based on availability of Compustat and CRSP data}

Column (1) shows the means for the different measures of hostility [Host(WSJ), Host(SDC), Host(Uns), Host(Pre), and Host(Factor)], deal characteristics (Pill, Auction, Success, Cash, Equity, Tender Offer, and Public Bidder), performance statistics (ROE, Sales Growth, Liquidity, D/E, M/B, P/E, and Size), and target stock price behavior (Runup, Markup, and Premium) defined in table 1 for the sample of firms with complete data (593 observations) available from Compustat and CRSP for analysis of the probit and regression models in tables 5 through 9. Columns (2) and (3) show estimates of the differences in means between the full sample of 2,346 cases in table 1 and the sample with complete data, with a t-statistic testing whether the difference is reliably different from zero using White's (1980) heteroskedasticity-consistent standard errors. Column (4) shows the proportion of successful and unsuccessful takeover bids for exchange-listed target firms for each year from 1975-96 for the cases with complete data available. Columns (5) and (6) show estimates of the differences in means between the full sample of 2,346 cases in table 3 and the sample with complete data, with a t-statistic testing whether the difference is reliably different from zero.

\begin{tabular}{lccccccc}
\hline & $(1)$ & $(2)$ & $(3)$ & & $(4)$ & $(5)$ & $(6)$ \\
& $\begin{array}{c}\text { Complete data } \\
\text { (N=593) }\end{array}$ & \multicolumn{2}{c}{$\begin{array}{c}\text { Probit Sample vs. } \\
\text { Full Sample }\end{array}$} & & \multicolumn{2}{c}{$\begin{array}{c}\text { Complete data } \\
\text { (N=593) }\end{array}$} & \multicolumn{2}{c}{$\begin{array}{c}\text { Probit Sample vs. } \\
\text { Variable }\end{array}$} & Mean & Diff & T-statistic & Year & Mean & Diff & T-statistic \\
\hline Host(WSJ) & 0.105 & 0.041 & 2.93 & 1975 & 0.000 & -0.028 & -7.10 \\
Host(SDC) & 0.256 & 0.070 & 3.11 & 1976 & 0.000 & -0.038 & -8.28 \\
Host(Uns) & 0.444 & 0.029 & 1.22 & 1977 & 0.000 & -0.066 & -11.15 \\
Host(Pre) & 0.514 & 0.093 & 3.94 & 1978 & 0.020 & -0.037 & -4.66 \\
Host(Factor) & 0.282 & 0.048 & 3.69 & 1979 & 0.005 & -0.070 & -10.06 \\
Pill & 0.155 & 0.083 & 5.17 & 1980 & 0.019 & -0.046 & -5.69 \\
Auction & 0.216 & 0.030 & 1.55 & 1981 & 0.034 & -0.010 & -1.09 \\
Success & 0.739 & -0.010 & -0.50 & 1982 & 0.025 & -0.022 & -2.69 \\
Cash & 0.624 & 0.057 & 2.48 & 1983 & 0.049 & 0.010 & 1.01 \\
Equity & 0.233 & -0.006 & -0.28 & 1984 & 0.094 & 0.055 & 4.23 \\
Tender Offer & 0.390 & 0.086 & 3.77 & 1985 & 0.099 & 0.055 & 4.15 \\
Public Bidder & 0.619 & 0.015 & 0.64 & 1986 & 0.115 & 0.047 & 3.29 \\
ROE & 0.123 & 0.051 & 8.70 & 1987 & 0.081 & 0.017 & 1.35 \\
Sales Growth & 0.105 & 0.042 & 4.17 & 1988 & 0.105 & 0.020 & 1.38 \\
Liquidity & 0.247 & 0.001 & 0.06 & 1989 & 0.074 & 0.016 & 1.32 \\
D/E & 0.561 & -0.691 & -4.23 & 1990 & 0.037 & 0.015 & 1.81 \\
M/B & 1.706 & 0.058 & 0.37 & 1991 & 0.017 & -0.009 & -1.36 \\
P/E & 16.243 & 4.621 & 7.17 & 1992 & 0.022 & 0.004 & 0.62 \\
Size & 12.297 & 1.057 & 13.57 & 1993 & 0.027 & 0.002 & 0.25 \\
Runup & 0.106 & -0.025 & -2.32 & 1994 & 0.040 & 0.014 & 1.52 \\
Markup & 0.117 & 0.028 & 1.94 & 1995 & 0.059 & 0.032 & 3.03 \\
Premium & 0.223 & 0.003 & 0.16 & 1996 & 0.078 & 0.039 & 3.26 \\
\hline & & & & & & & \\
\hline
\end{tabular}


Table 5

\section{Hostility prediction models, 1975-96}

Probit models predicting whether successful and unsuccessful takeover bids for exchange-listed target firms from 1975-96 are hostile, using four measures of hostility. The dependent variables are dummy variables that equal one when a hostile bid is made for a target firm, and zero otherwise. Host(WSJ) is based on descriptions in the Wall Street Journal Index or Dow Jones News Retrieval, Host(SDC) is based on whether the target firm resisted an unsolicited offer as determined by the Securities Data Corporation (SDC), Host(Uns) is based on whether the initial or winning bid is unsolicited, and Host(Pre) is based on whether the target firm is in play (someone has filed a 13D form with the S.E.C. showing an accumulation of shares within the past 12 months) or the subject of a takeover rumor reported in DJNR. Several variables measuring the performance of the target firm before the first bid are used in the model. ROE is earnings divided by average stockholder's (book) equity and Sales Growth is the growth in sales over the fiscal year before the first bid. Liquidity is the ratio of net liquid assets to total assets, D/E is the longterm debt to book equity, M/B is the ratio of market to book value of stockholder's equity, P/E is the ratio of stock price to the earnings for the last fiscal year, and Size is the logarithm of the market value of common stock, all measured at the end of the fiscal year before the first bid. Dummy variables equal to one when the first bid occurs from 1980-84, or 1985-89, or 1990-96, and zero otherwise, allow for secular variation. The last two columns contain the coefficients and t-statistics for a regression of the hostility factor (principal component), Host(Factor), created from the three hostility variables with complete data [Host(WSJ), Host(Uns), and Host(Pre)] on the explanatory variables from the probit model.

\begin{tabular}{|c|c|c|c|c|c|c|c|c|c|c|c|c|c|c|}
\hline \multirow[b]{2}{*}{ Variable } & \multicolumn{3}{|c|}{$\underline{\text { Host(WSJ) }}$} & \multicolumn{3}{|c|}{$\underline{\text { Host(SDC) }}$} & \multicolumn{3}{|c|}{$\underline{\text { Host(Uns) }}$} & \multicolumn{3}{|c|}{$\underline{\text { Host(Pre) }}$} & \multicolumn{2}{|c|}{ Host(Factor) } \\
\hline & Coef & T-Statistic & $\begin{array}{c}\text { Marginal } \\
\text { Effect }\end{array}$ & Coef & T-Statistic & $\begin{array}{c}\text { Marginal } \\
\text { Effect }\end{array}$ & Coef & T-Statistic & $\begin{array}{c}\text { Marginal } \\
\text { Effect }\end{array}$ & Coef & T-Statistic & $\begin{array}{c}\text { Marginal } \\
\text { Effect }\end{array}$ & Coef & T-Statistic \\
\hline Constant & -4.692 & -7.66 & -0.638 & -3.145 & -4.57 & $\begin{array}{l}-0.882 \\
\end{array}$ & -0.153 & -0.43 & -0.056 & -1.660 & -4.57 & -0.603 & -0.092 & -1.36 \\
\hline ROE & -2.413 & -2.79 & -0.328 & -0.104 & -0.12 & -0.029 & -1.192 & -2.11 & -0.439 & -0.483 & -0.90 & -0.175 & -0.321 & -3.65 \\
\hline Sales Growth & -0.715 & -1.83 & -0.097 & -0.187 & -0.54 & -0.052 & -0.433 & -1.89 & -0.159 & -0.268 & -1.19 & -0.097 & -0.121 & -3.29 \\
\hline Liquidity & 0.386 & 1.02 & 0.052 & 0.236 & 0.66 & 0.066 & -0.027 & -0.12 & -0.010 & -0.262 & -1.13 & -0.095 & 0.003 & 0.07 \\
\hline $\mathrm{D} / \mathrm{E}$ & -0.243 & -1.55 & -0.033 & -0.082 & -0.72 & -0.023 & 0.018 & 0.32 & 0.007 & 0.117 & 2.24 & 0.042 & 0.007 & 0.93 \\
\hline $\mathrm{M} / \mathrm{B}$ & -0.068 & -0.82 & -0.009 & -0.226 & -2.83 & -0.063 & -0.151 & -3.01 & -0.055 & -0.055 & -1.48 & -0.020 & -0.018 & -2.59 \\
\hline $\mathrm{P} / \mathrm{E}$ & -0.020 & -2.21 & -0.003 & -0.006 & -0.89 & -0.002 & -0.003 & -0.66 & -0.001 & -0.003 & -0.65 & -0.001 & -0.002 & -2.64 \\
\hline Size & 0.359 & 7.49 & 0.049 & 0.256 & 5.68 & 0.072 & 0.032 & 1.11 & 0.012 & 0.124 & 4.29 & 0.045 & 0.038 & 6.73 \\
\hline $1980-84$ & -0.511 & -2.85 & -0.069 & -0.508 & -1.39 & -0.142 & -0.114 & -1.05 & -0.042 & 0.363 & 3.30 & 0.132 & -0.018 & -0.94 \\
\hline $1985-89$ & -0.188 & -1.11 & -0.026 & -0.016 & -0.04 & -0.004 & 0.402 & 3.59 & 0.148 & 0.687 & 6.07 & 0.250 & 0.088 & 4.14 \\
\hline $1990-96$ & -0.675 & -2.88 & -0.092 & -0.457 & -1.24 & -0.128 & -0.356 & -2.43 & -0.131 & -0.134 & -0.93 & -0.049 & -0.096 & -3.37 \\
\hline $\mathrm{R}^{2}$ & & 0.108 & & & 0.119 & & & 0.078 & & & 0.099 & & & 0.133 \\
\hline Log-likelihood & & -275.6 & & & -304.0 & & & -704.5 & & & -697.0 & & & \\
\hline Sample Size, N & & 1,096 & & & 593 & & & 1,096 & & & 1,096 & & & 1,096 \\
\hline
\end{tabular}

Note: The marginal effect column transforms the probit coefficient into the marginal effect of the variable on the estimated probability, evaluated at the sample means of the explanatory variables. 


\section{Table 6}

How does hostility affect the probability of success?

A probit model predicts whether takeover bids for exchange-listed target firms from 1975-96 will be successful. The dependent variable is a dummy variable that equals one when a bid

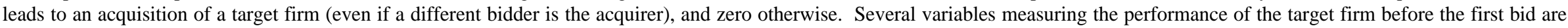

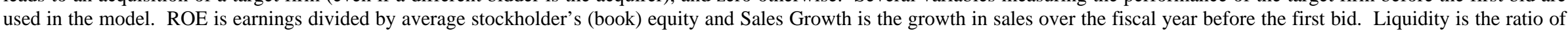

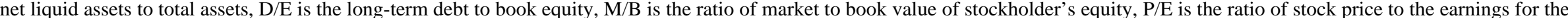

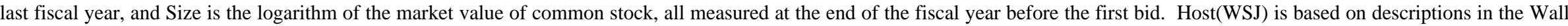

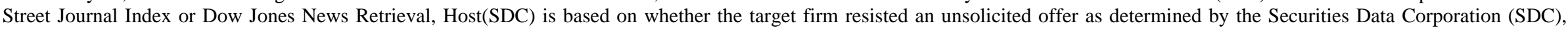

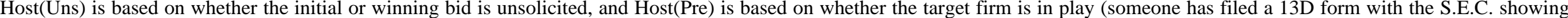

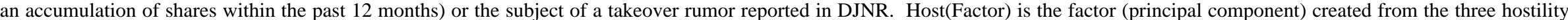

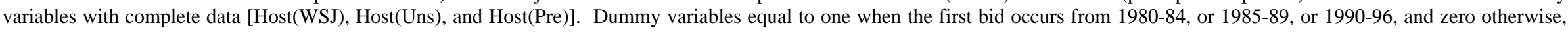
allow for secular variation.

\begin{tabular}{|c|c|c|c|c|c|c|c|c|c|}
\hline Variable & Coefficient & T-Statistic & Marginal Effect & Coefficient & T-Statistic & $\begin{array}{c}\text { Marginal } \\
\text { Effect }\end{array}$ & Coefficient & T-Statistic & $\begin{array}{c}\text { Marginal } \\
\text { Effect }\end{array}$ \\
\hline Constant & 1.676 & 2.28 & 0.449 & 0.818 & 2.03 & 0.232 & 0.249 & 0.65 & 0.073 \\
\hline ROE & -0.519 & -0.64 & -0.139 & -0.622 & -0.99 & -0.176 & -0.641 & -1.03 & -0.189 \\
\hline Sales Growth & -0.566 & -1.69 & -0.152 & -0.425 & -1.70 & -0.120 & -0.420 & -1.71 & -0.124 \\
\hline Liquidity & 0.649 & 1.81 & 0.174 & 0.316 & 1.22 & 0.089 & 0.364 & 1.44 & 0.107 \\
\hline $\mathrm{D} / \mathrm{E}$ & -0.151 & -1.77 & -0.041 & -0.186 & -3.23 & -0.053 & -0.201 & -3.53 & -0.059 \\
\hline $\mathrm{M} / \mathrm{B}$ & 0.099 & 1.68 & 0.026 & 0.118 & 2.40 & 0.033 & 0.136 & 2.71 & 0.040 \\
\hline $\mathrm{P} / \mathrm{E}$ & -0.001 & -0.25 & 0.000 & -0.005 & -1.25 & -0.002 & -0.006 & -1.51 & -0.002 \\
\hline Size & 0.020 & 0.43 & 0.005 & 0.041 & 1.25 & 0.012 & 0.074 & 2.34 & 0.022 \\
\hline Host(WSJ) & -0.393 & -1.85 & -0.105 & 0.019 & 0.12 & 0.005 & & & \\
\hline Host(SDC) & 0.362 & 2.12 & 0.097 & & & & & & \\
\hline Host(Uns) & -1.260 & -8.34 & -0.338 & -0.896 & -9.62 & -0.254 & & & \\
\hline Host(Pre) & -0.239 & -1.85 & -0.064 & -0.464 & -5.08 & -0.132 & & & \\
\hline Host(Factor) & & & & & & & -1.536 & -8.98 & -0.452 \\
\hline $1980-84$ & -0.555 & -1.31 & -0.149 & 0.252 & 2.01 & 0.071 & 0.182 & 1.49 & 0.053 \\
\hline $1985-89$ & -0.522 & -1.27 & -0.140 & 0.066 & 0.52 & 0.019 & -0.066 & -0.55 & -0.020 \\
\hline $1990-96$ & -0.907 & -2.13 & -0.243 & -0.171 & -1.07 & -0.048 & -0.194 & -1.24 & -0.057 \\
\hline $\mathrm{R}^{2}$ & & 0.196 & & & 0.156 & & & 0.107 & \\
\hline Log-likelihood & & -282.3 & & & -551.0 & & & -574.0 & \\
\hline Sample Size, N & & 593 & & & 1,096 & & & 1,096 & \\
\hline
\end{tabular}

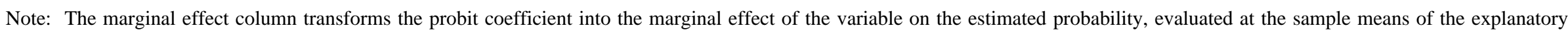
variables. 


\section{Table 7}

Is the pre-bid stock price runup related to hostility?

A regression model is used to explain the pre-bid stock price runup [the cumulative abnormal return to the target firm's stock for trading days $(-63,-1)$ relative to the date of the first bid] for successful and unsuccessful takeover bids for exchange-listed target firms, 1975-96. Several variables measuring the performance of the target firm before the first bid are used in the model. ROE is earnings divided by average stockholder's (book) equity and Sales Growth is the growth in sales over the fiscal year before the first bid. Liquidity is the ratio of net liquid assets to total assets, D/E is the long-term debt to book equity, M/B is the ratio of market to book value of stockholder's equity, $\mathrm{P} / \mathrm{E}$ is the ratio of stock price to the earnings for the last fiscal year, and Size is the logarithm of the market value of common stock, all measured at the end of the fiscal year before the first bid. Host(WSJ) is based on descriptions in the Wall Street Journal Index or Dow Jones News Retrieval, Host(SDC) is based on whether the target firm resisted an unsolicited offer as determined by the Securities Data Corporation (SDC), Host(Uns) is based on whether the initial or winning bid is unsolicited, and Host(Pre) is based on whether the target firm is in play (someone has filed a 13D form with the S.E.C. showing an accumulation of shares within the past 12 months) or the subject of a takeover rumor reported in DJNR. Host(Factor) is the factor (principal component) created from the three hostility variables with complete data [Host(WSJ), Host(Uns), and Host(Pre)]. Dummy variables equal to one when the first bid occurs from 1980-84, or 1985-89, or 199096, and zero otherwise, allow for secular variation. T-statistics use White's (1980) heteroskedasticityconsistent covariance matrix.

\begin{tabular}{|c|c|c|c|c|c|c|}
\hline Variable & Coefficient & T-Statistic & Coefficient & T-Statistic & Coefficient & T-Statistic \\
\hline Constant & 0.356 & 3.27 & 0.392 & 6.05 & 0.361 & 5.62 \\
\hline ROE & 0.011 & 0.10 & -0.100 & -1.07 & -0.093 & -0.97 \\
\hline Sales Growth & -0.018 & -0.39 & -0.031 & -0.83 & -0.031 & -0.79 \\
\hline Liquidity & -0.098 & -2.06 & -0.094 & -2.55 & -0.098 & -2.65 \\
\hline $\mathrm{D} / \mathrm{E}$ & 0.023 & 2.31 & 0.003 & 0.30 & 0.005 & 0.54 \\
\hline $\mathrm{M} / \mathrm{B}$ & -0.015 & -2.88 & -0.007 & -1.04 & -0.006 & -0.96 \\
\hline $\mathrm{P} / \mathrm{E}$ & -0.001 & -1.62 & -0.001 & -1.89 & -0.001 & -1.91 \\
\hline Size & -0.011 & -1.57 & -0.009 & -1.78 & -0.006 & -1.21 \\
\hline Host(WSJ) & -0.048 & -1.82 & -0.007 & -0.40 & & \\
\hline Host(SDC) & 0.065 & 2.89 & & & & \\
\hline Host(Uns) & -0.095 & -4.40 & -0.052 & -3.75 & & \\
\hline Host(Pre) & 0.081 & 4.53 & 0.055 & 4.13 & & \\
\hline Host(Factor) & & & & & -0.034 & -1.53 \\
\hline $1980-84$ & -0.032 & -0.53 & -0.079 & -4.45 & -0.070 & -3.89 \\
\hline $1985-89$ & -0.077 & -1.31 & -0.113 & -6.00 & -0.104 & -5.54 \\
\hline $1990-96$ & -0.120 & -1.93 & -0.160 & -6.66 & -0.158 & -6.46 \\
\hline $\mathrm{R}^{2}$ & & 0.133 & & 0.119 & & 0.094 \\
\hline $\mathrm{S}(\mathrm{u})$ & & 0.201 & & 0.208 & & 0.211 \\
\hline Sample Size, N & & 579 & & 1,095 & & 1,095 \\
\hline
\end{tabular}


Table 8

\section{Is the takeover premium related to hostility?}

A regression model is used to explain the takeover premium [the cumulative abnormal return to the target firm's stock for trading days $(-63,126)$ relative to the date of the first bid] for successful and unsuccessful takeover bids for exchange-listed target firms, 1975-96. Several variables measuring the performance of the target firm before the first bid are used in the model. ROE is earnings divided by average stockholder's (book) equity and Sales Growth is the growth in sales over the fiscal year before the first bid. Liquidity is the ratio of net liquid assets to total assets, D/E is the long-term debt to book equity, M/B is the ratio of market to book value of stockholder's equity, $\mathrm{P} / \mathrm{E}$ is the ratio of stock price to the earnings for the last fiscal year, and Size is the logarithm of the market value of common stock, all measured at the end of the fiscal year before the first bid. Host(WSJ) is based on descriptions in the Wall Street Journal Index or Dow Jones News Retrieval, Host(SDC) is based on whether the target firm resisted an unsolicited offer as determined by the Securities Data Corporation (SDC). Host(Uns) is based on whether the initial or winning bid is unsolicited, and Host(Pre) is based on whether the target firm is in play (someone has filed a 13D form with the S.E.C. showing an accumulation of shares within the past 12 months) or the subject of a takeover rumor reported in DJNR. Host(Factor) is the factor (principal component) created from the three hostility variables with complete data [Host(WSJ), Host(Uns), and Host(Pre)]. Dummy variables equal to one when the first bid occurs from 1980-84, or 1985-89, or 1990-96, and zero otherwise, allow for secular variation. In addition, in columns (3)-(4), (7)-(8), and (11)-(12), several variables that are only known during the takeover contest are included in the model. Pill equals one if the target firm has a poison pill in place, Auction equals one if there are multiple bidders, Cash equals one if there is an all-cash payment to target shareholders, and Tender Offer equals one if the deal is a tender offer. T-statistics use White's (1980) heteroskedasticity-consistent covariance matrix.

\begin{tabular}{|c|c|c|c|c|c|c|c|c|c|c|c|c|}
\hline Variable & $\begin{array}{c}\text { (1) } \\
\text { Coefficient }\end{array}$ & $\begin{array}{c}(2) \\
\text { T-Statistic }\end{array}$ & $\begin{array}{c}\text { (3) } \\
\text { Coefficient }\end{array}$ & $\begin{array}{c}\text { (4) } \\
\text { T-Statistic }\end{array}$ & $\begin{array}{c}\text { (5) } \\
\text { Coefficient }\end{array}$ & $\begin{array}{c}\text { (6) } \\
\text { T-Statistic }\end{array}$ & $\begin{array}{c}\text { (7) } \\
\text { Coefficient }\end{array}$ & $\begin{array}{c}\text { (8) } \\
\text { T-Statistic }\end{array}$ & $\begin{array}{c}\text { (9) } \\
\text { Coefficient }\end{array}$ & $\begin{array}{c}\text { (10) } \\
\text { T-Statistic }\end{array}$ & $\begin{array}{c}\text { (11) } \\
\text { Coefficient }\end{array}$ & $\begin{array}{c}\text { (12) } \\
\text { T-Statistic }\end{array}$ \\
\hline Constant & 0.734 & 3.82 & 0.564 & 2.82 & 0.490 & 4.67 & 0.423 & 3.85 & 0.450 & 4.40 & 0.378 & 3.45 \\
\hline ROE & 0.110 & 0.52 & 0.153 & 0.75 & -0.032 & -0.19 & 0.020 & 0.13 & -0.036 & -0.22 & 0.018 & 0.11 \\
\hline Sales Growth & -0.044 & -0.44 & -0.022 & -0.22 & -0.083 & -1.10 & -0.073 & -1.00 & -0.084 & -1.12 & -0.073 & -1.01 \\
\hline Liquidity & -0.153 & -1.69 & -0.219 & -2.52 & -0.096 & -1.46 & -0.146 & -2.29 & -0.086 & -1.31 & -0.140 & -2.19 \\
\hline $\mathrm{D} / \mathrm{E}$ & -0.016 & -0.46 & -0.013 & -0.40 & -0.024 & -1.16 & -0.019 & -1.01 & -0.027 & -1.32 & -0.021 & -1.12 \\
\hline $\mathrm{M} / \mathrm{B}$ & -0.001 & -0.07 & -0.005 & -0.35 & -0.001 & -0.07 & -0.004 & -0.34 & 0.000 & 0.03 & -0.003 & -0.25 \\
\hline $\mathrm{P} / \mathrm{E}$ & -0.003 & -2.00 & -0.002 & -1.75 & -0.003 & -2.29 & -0.002 & -1.86 & -0.003 & -2.38 & -0.002 & -1.94 \\
\hline Size & -0.033 & -2.82 & -0.028 & -2.30 & -0.012 & -1.41 & -0.013 & -1.51 & -0.010 & -1.20 & -0.011 & -1.22 \\
\hline Host(WSJ) & -0.046 & -0.87 & -0.070 & -1.42 & 0.090 & 2.41 & 0.011 & 0.30 & & & & \\
\hline Host(SDC) & 0.151 & 3.22 & 0.061 & 1.28 & & & & & & & & \\
\hline Host(Uns) & -0.098 & -2.48 & -0.106 & -2.72 & -0.026 & -1.03 & -0.079 & -3.03 & & & & \\
\hline Host(Pre) & 0.008 & 0.24 & -0.013 & -0.43 & -0.052 & -2.16 & -0.056 & -2.39 & & & & \\
\hline Host(Factor) & & & & & & & & & -0.005 & -0.13 & -0.147 & -3.21 \\
\hline 1980-84 & 0.008 & 0.07 & 0.026 & 0.24 & 0.004 & 0.14 & -0.007 & -0.23 & -0.007 & -0.22 & -0.014 & -0.46 \\
\hline 1985-89 & -0.025 & -0.24 & -0.043 & -0.40 & -0.022 & -0.68 & -0.058 & -1.79 & -0.039 & -1.23 & -0.069 & -2.13 \\
\hline 1990-96 & -0.018 & -0.16 & 0.028 & 0.25 & -0.037 & -0.84 & -0.019 & -0.44 & -0.039 & -0.89 & -0.019 & -0.44 \\
\hline Pill & & & 0.035 & 0.77 & & & 0.055 & 1.28 & & & 0.048 & 1.12 \\
\hline Auction & & & 0.125 & 3.07 & & & 0.086 & 2.61 & & & 0.082 & 2.51 \\
\hline Cash & & & 0.098 & 2.64 & & & 0.088 & 3.33 & & & 0.086 & 3.24 \\
\hline Tender Offer & & & 0.151 & 4.62 & & & 0.141 & 5.84 & & & 0.148 & 6.09 \\
\hline $\mathrm{R}^{2}$ & & 0.048 & & 0.133 & & 0.029 & & 0.097 & & 0.021 & & 0.091 \\
\hline $\mathrm{S}(\mathrm{u})$ & & 0.367 & & 0.351 & & 0.368 & & 0.355 & & 0.369 & & 0.356 \\
\hline Sample Size, N & & 593 & & 593 & & 1,095 & & 1,095 & & 1,095 & & 1,095 \\
\hline
\end{tabular}


Table 9

How does hostility affect the probability of an auction?

A probit model predicts whether takeover bids for exchange-listed target firms from 1975-96 will be lead to competition from other bidders (an auction). The dependent variable is a dummy variable that equals one when a bid is followed by a formal bid for the target firm by a different bidder within a year, and zero otherwise. Several variables measuring the performance of the target firm before the first bid are used in the model. ROE is earnings divided by average stockholder's (book) equity and Sales Growth is the growth in sales over the fiscal year before the first bid. Liquidity is the ratio of net liquid assets to total assets, D/E is the long-term debt to book equity, M/B is the ratio of market to book value of stockholder's equity, P/E is the ratio of stock price to the earnings for the last fiscal year, and Size is the logarithm of the market value of common stock, all measured at the end of the fiscal year before the first bid. Host(WSJ) is based on descriptions in the Wall Street Journal Index or Dow Jones News Retrieval, Host(SDC) is based on whether the target firm resisted an unsolicited offer as determined by the Securities Data Corporation (SDC), Host(Uns) is based on whether the initial or winning bid is unsolicited, and Host(Pre) is based on whether the target firm is in play (someone has filed a 13D form with the S.E.C. showing an accumulation of shares within the past 12 months) or the subject of a takeover rumor reported in DJNR. Host(Factor) is the factor (principal component) created from the three hostility variables with complete data [Host(WSJ), Host(Uns), and Host(Pre)]. Dummy variables equal to one when the first bid occurs from 1980-84, or 1985-89, or 1990-96, and zero otherwise, allow for secular variation.

\begin{tabular}{|c|c|c|c|c|c|c|c|c|c|}
\hline Variable & $\begin{array}{c}(1) \\
\text { Coefficient }\end{array}$ & $\begin{array}{c}(2) \\
\text { T-Statistic }\end{array}$ & $\begin{array}{c}(3) \\
\text { Marginal } \\
\text { Effect }\end{array}$ & $\begin{array}{c}(4) \\
\text { Coefficient }\end{array}$ & $\begin{array}{c}(5) \\
\text { T-Statistic }\end{array}$ & $\begin{array}{c}\text { (6) } \\
\text { Marginal } \\
\text { Effect }\end{array}$ & $\begin{array}{c}(7) \\
\text { Coefficient }\end{array}$ & $\begin{array}{c}(8) \\
\text { T-Statistic }\end{array}$ & $\begin{array}{c}(9) \\
\text { Marginal } \\
\text { Effect }\end{array}$ \\
\hline Constant & -0.938 & -1.27 & -0.236 & -1.770 & -3.92 & -0.423 & -1.401 & -3.24 & -0.337 \\
\hline ROE & -0.106 & -0.13 & -0.027 & -0.613 & -0.96 & -0.146 & -0.657 & -1.04 & -0.158 \\
\hline Sales Growth & -0.267 & -0.72 & -0.067 & 0.017 & 0.06 & 0.004 & 0.024 & 0.08 & 0.006 \\
\hline Liquidity & 0.190 & 0.51 & 0.048 & 0.272 & 0.97 & 0.065 & 0.256 & 0.92 & 0.062 \\
\hline $\mathrm{D} / \mathrm{E}$ & 0.004 & 0.04 & 0.001 & 0.024 & 0.40 & 0.006 & 0.029 & 0.49 & 0.007 \\
\hline $\mathrm{M} / \mathrm{B}$ & 0.049 & 0.94 & 0.012 & 0.042 & 0.97 & 0.010 & 0.035 & 0.81 & 0.008 \\
\hline $\mathrm{P} / \mathrm{E}$ & 0.002 & 0.31 & 0.000 & -0.004 & -0.85 & -0.001 & -0.004 & -0.81 & -0.001 \\
\hline Size & -0.054 & -1.09 & -0.013 & 0.027 & 0.76 & 0.006 & 0.004 & 0.12 & 0.001 \\
\hline Host(WSJ) & 0.109 & 0.53 & 0.028 & 0.567 & 3.83 & 0.136 & & & \\
\hline Host(SDC) & 0.618 & 3.86 & 0.155 & & & & & & \\
\hline Host(Uns) & 0.505 & 3.41 & 0.127 & 0.763 & 7.60 & 0.182 & & & \\
\hline Host(Pre) & 0.392 & 2.95 & 0.099 & 0.278 & 2.83 & 0.066 & & & \\
\hline Host(Factor) & & & & & & & 1.700 & 9.44 & 0.409 \\
\hline Runup & 0.248 & 0.82 & 0.062 & 0.011 & 0.05 & 0.003 & -0.056 & -0.26 & -0.014 \\
\hline $1980-84$ & 0.045 & 0.12 & 0.011 & 0.021 & 0.16 & 0.005 & 0.022 & 0.17 & 0.005 \\
\hline $1985-89$ & -0.059 & -0.16 & -0.015 & -0.074 & -0.54 & -0.018 & -0.045 & -0.34 & -0.011 \\
\hline $1990-96$ & -0.130 & -0.33 & -0.033 & -0.128 & -0.70 & -0.030 & -0.144 & -0.79 & -0.035 \\
\hline $\mathrm{R}^{2}$ & & 0.119 & & & 0.107 & & & 0.098 & \\
\hline Log-likelihood & & -268.8 & & & -472.3 & & & -477.6 & \\
\hline Sample Size, N & & 593 & & & 1,095 & & & 1,095 & \\
\hline
\end{tabular}

Note: The marginal effect column transforms the probit coefficient into the marginal effect of the variable on the estimated probability, evaluated at the sample means of the explanatory variables. 
Table 10

Tests for sample selection bias based on availability of CRSP stock returns for the bidder firm

Column (1) shows the means for the different measures of hostility [Host(WSJ), Host(SDC), Host(Uns), Host(Pre), and Host(Factor)], deal characteristics (Pill, Auction, Success, Cash, Equity, and Tender Offer) and characteristics of the target firm (stock price runup, markup, and premium surrounding the first offer announcement, and the log of equity capitalization for the target firm), defined in table 1 for the sample of firms with data available from CRSP for returns to the First Bidder's stock (1,286 observations). Columns (2) and (3) show estimates of the differences in means between the full sample of 2,346 cases in table 1 and the sample with bidder return data, with a t-statistic testing whether the difference is reliably different from zero using White's (1980) heteroskedasticity-consistent standard errors. Columns (4) and (5) estimates of the differences in means between the full sample of 2,346 cases in table 1 and the sample with complete data available for estimating the regression models in table 11 (726 observations), with a t-statistic testing whether the difference is reliably different from zero. Columns (6) and (7) show estimates of the differences in means between the full sample of 2,346 cases in table 1 and the sample with complete data (omitting the SDC measure of hostility, 1,253 observations), with a t-statistic testing whether the difference is reliably different from zero.

\begin{tabular}{|c|c|c|c|c|c|c|c|}
\hline \multirow[b]{3}{*}{ Variable } & \multirow{3}{*}{$\begin{array}{c}(1) \\
\text { Data on } \\
\text { Bidder Returns } \\
(\mathrm{N}=1,286) \\
\text { Mean }\end{array}$} & \multirow{2}{*}{\multicolumn{2}{|c|}{$\begin{array}{c}\text { (2) } \\
\text { Bidder Return Sample } \\
\text { vs. } \\
\text { Full Sample }\end{array}$}} & (4) & (5) & (6) & (7) \\
\hline & & & & \multicolumn{2}{|c|}{$\begin{array}{l}\text { Regression Sample } \\
\text { vs. } \\
\text { Full Sample (N=726) }\end{array}$} & \multicolumn{2}{|c|}{$\begin{array}{c}\text { Regression Sample (no SDC } \\
\text { vs. } \\
\text { Full Sample }(\mathrm{N}=1,253)\end{array}$} \\
\hline & & Diff & T-statistic & Diff & T-statistic & Diff & T-statistic \\
\hline Host(WSJ) & 0.083 & 0.020 & 1.86 & 0.028 & 2.27 & 0.022 & 2.09 \\
\hline Host(SDC) & 0.189 & -0.059 & -2.64 & -0.051 & -2.32 & & \\
\hline Host(Uns) & 0.311 & -0.246 & -12.29 & -0.154 & -7.27 & -0.238 & -11.92 \\
\hline Host(Pre) & 0.403 & -0.092 & -4.50 & -0.008 & -0.34 & -0.089 & -4.35 \\
\hline Host(Factor) & 0.211 & -0.078 & -7.46 & -0.031 & -2.64 & -0.074 & -7.07 \\
\hline Pill & 0.075 & -0.040 & -3.30 & 0.043 & 3.09 & -0.040 & -3.31 \\
\hline Auction & 0.152 & -0.091 & -5.49 & -0.045 & -2.64 & -0.088 & -5.36 \\
\hline Success & 0.782 & 0.079 & 4.38 & 0.098 & 5.36 & 0.090 & 5.01 \\
\hline Cash & 0.425 & -0.346 & -18.33 & -0.217 & -9.92 & -0.331 & -17.34 \\
\hline Equity & 0.366 & 0.286 & 18.09 & 0.215 & 10.59 & 0.276 & 17.12 \\
\hline Tender Offer & 0.313 & -0.026 & -1.35 & 0.026 & 1.22 & -0.015 & -0.75 \\
\hline \multicolumn{8}{|l|}{ Target: } \\
\hline Runup & 0.124 & 0.000 & 0.01 & -0.030 & -2.76 & -0.001 & -0.05 \\
\hline Markup & 0.100 & 0.009 & 0.63 & 0.064 & 4.54 & 0.009 & 0.64 \\
\hline Premium & 0.224 & 0.009 & 0.48 & 0.034 & 1.82 & 0.008 & 0.46 \\
\hline Size & 11.674 & 0.358 & 4.98 & 0.970 & 12.99 & 0.338 & 4.71 \\
\hline \multicolumn{8}{|l|}{ First Bidder } \\
\hline Runup & 0.013 & & & -0.008 & -0.99 & 0.004 & 0.13 \\
\hline Markup & -0.023 & & & -0.021 & -1.61 & 0.052 & 1.35 \\
\hline Premium & -0.010 & & & -0.030 & -1.88 & 0.056 & 1.05 \\
\hline Size & 16.855 & & & 0.302 & 4.85 & 0.184 & 1.23 \\
\hline
\end{tabular}


Table 11

How does hostility affect the bidder's stock price?

A regression model is used to explain the cumulative abnormal return to the bidder firm's stock for trading days (-63, 126) relative to the date of the first bid for successful and unsuccessful takeover bids for exchange-listed target firms, 1975-96. Host(WSJ) is based on descriptions in the Wall Street Journal Index or Dow Jones News Retrieval, Host(SDC) is based on whether the target firm resisted an unsolicited offer as determined by the Securities Data Corporation (SDC), Host(Uns) is based on whether the initial or winning bid is unsolicited, and Host(Pre) is based on whether the target firm is in play (someone has filed a 13D form with the S.E.C. showing an accumulation of shares within the past 12 months) or the subject of a takeover rumor reported in DJNR. Host(Factor) is the factor (principal component) created from the three hostility variables with complete data [Host(WSJ), Host(Uns, and Host(Pre)]. Target size and Bidder size are the logarithms of the market values of common stocks, all measured at the end of the fiscal year before the first bid. Target runup is the cumulative abnormal return to the target firm's stock for trading days $(-63,-1)$ before the first bid and Target markup is the cumulative abnormal return to the target firm's stock for trading days $(0,126)$ based on CRSP value-weighted market model estimates for trading days $(-316,-64)$. Dummy variables equal to one when the first bid occurs from 1980-84, or 1985-89, or 1990-96, and zero otherwise, allow for secular variation. In addition, in columns (3) and (7), several variables that may be only known during the takeover contest are included in the model. Pill equals one if the target firm has a poison pill in place, Auction equals one if there are multiple bidders, Cash equals one if there is an all-cash payment to target shareholders, Tender offer equals one if the deal is a tender offer, and Successful equals one if the target firm is taken over by some bidder as a result of a bid that occurs within twelve months of the first bid. T-statistics use White's (1980) heteroskedasticity-consistent covariance matrix.

\begin{tabular}{|c|c|c|c|c|c|c|c|c|c|c|c|c|}
\hline Variable & $\begin{array}{c}\text { (1) } \\
\text { Coefficient }\end{array}$ & $\begin{array}{c}(2) \\
\text { T-Statistic }\end{array}$ & $\begin{array}{c}\text { (3) } \\
\text { Coefficient }\end{array}$ & $\begin{array}{c}(4) \\
\text { T-Statistic }\end{array}$ & $\begin{array}{c}\text { (5) } \\
\text { Coefficient }\end{array}$ & $\begin{array}{c}(6) \\
\text { T-Statistic }\end{array}$ & $\begin{array}{c}\text { (7) } \\
\text { Coefficient }\end{array}$ & $\begin{array}{c}(8) \\
\text { T-Statistic }\end{array}$ & $\begin{array}{c}(9) \\
\text { Coefficient }\end{array}$ & $\begin{array}{c}(10) \\
\text { T-Statistic }\end{array}$ & $\begin{array}{c}(11) \\
\text { Coefficient }\end{array}$ & $\begin{array}{c}(12) \\
\text { T-Statistic }\end{array}$ \\
\hline Constant & -0.804 & -2.69 & -0.756 & -2.48 & -0.296 & -1.84 & -0.257 & -1.65 & -0.289 & -1.86 & -0.247 & -1.65 \\
\hline Host(WSJ) & 0.048 & 1.08 & 0.058 & 1.29 & -0.023 & -0.74 & -0.020 & -0.62 & & & & \\
\hline Host(SDC) & -0.025 & -0.67 & -0.042 & -1.16 & & & & & & & & \\
\hline Host(Uns) & -0.002 & -0.06 & 0.008 & 0.26 & -0.015 & -0.74 & -0.007 & -0.33 & & & & \\
\hline Host(Pre) & -0.047 & -2.12 & -0.051 & -2.29 & -0.039 & -2.30 & -0.038 & -2.23 & & & & \\
\hline Host(Factor) & & & & & & & & & -0.073 & -2.17 & -0.063 & -1.69 \\
\hline Target size & -0.002 & -0.25 & -0.005 & -0.71 & 0.001 & 0.25 & 0.000 & -0.02 & 0.001 & 0.21 & 0.000 & -0.06 \\
\hline Bidder size & 0.042 & 2.40 & 0.041 & 2.34 & 0.018 & 1.90 & 0.016 & 1.76 & 0.017 & 1.92 & 0.015 & 1.76 \\
\hline Target runup & 0.114 & 1.68 & 0.104 & 1.52 & 0.106 & 2.35 & 0.093 & 2.04 & 0.096 & 2.09 & 0.082 & 1.76 \\
\hline Target markup & 0.104 & 2.64 & 0.092 & 1.96 & 0.113 & 4.02 & 0.102 & 3.28 & 0.121 & 4.39 & 0.109 & 3.62 \\
\hline $1980-84$ & 0.109 & 2.30 & 0.111 & 3.15 & -0.028 & -1.27 & -0.031 & -1.37 & -0.033 & -1.48 & -0.035 & -1.59 \\
\hline $1985-89$ & 0.083 & 1.83 & -0.065 & -1.99 & -0.030 & -1.38 & -0.047 & -2.10 & -0.036 & -1.66 & -0.054 & -2.36 \\
\hline $1990-96$ & 0.056 & 1.12 & -0.010 & -0.43 & -0.077 & -2.70 & -0.078 & -2.71 & -0.079 & -2.75 & -0.080 & -2.76 \\
\hline Pill & & & 0.033 & 1.25 & & & 0.079 & 2.44 & & & 0.076 & 2.39 \\
\hline Auction & & & 0.026 & 0.69 & & & -0.084 & -3.28 & & & -0.082 & -3.18 \\
\hline Cash & & & 0.114 & 2.46 & & & 0.003 & 0.16 & & & 0.006 & 0.29 \\
\hline Tender offer & & & 0.067 & 1.49 & & & 0.041 & 2.02 & & & 0.043 & 2.11 \\
\hline Successful & & & 0.057 & 1.15 & & & 0.020 & 0.79 & & & 0.019 & 0.73 \\
\hline $\mathrm{R}^{2}$ & 0.051 & & 0.073 & & 0.042 & & 0.060 & & 0.040 & & 0.057 & \\
\hline $\mathrm{S}(\mathrm{u})$ & 0.279 & & 0.277 & & 0.277 & & 0.275 & & 0.277 & & 0.275 & \\
\hline Sample Size, N & 726 & & 726 & & 1,253 & & 1,253 & & 1,253 & & 1,253 & \\
\hline
\end{tabular}




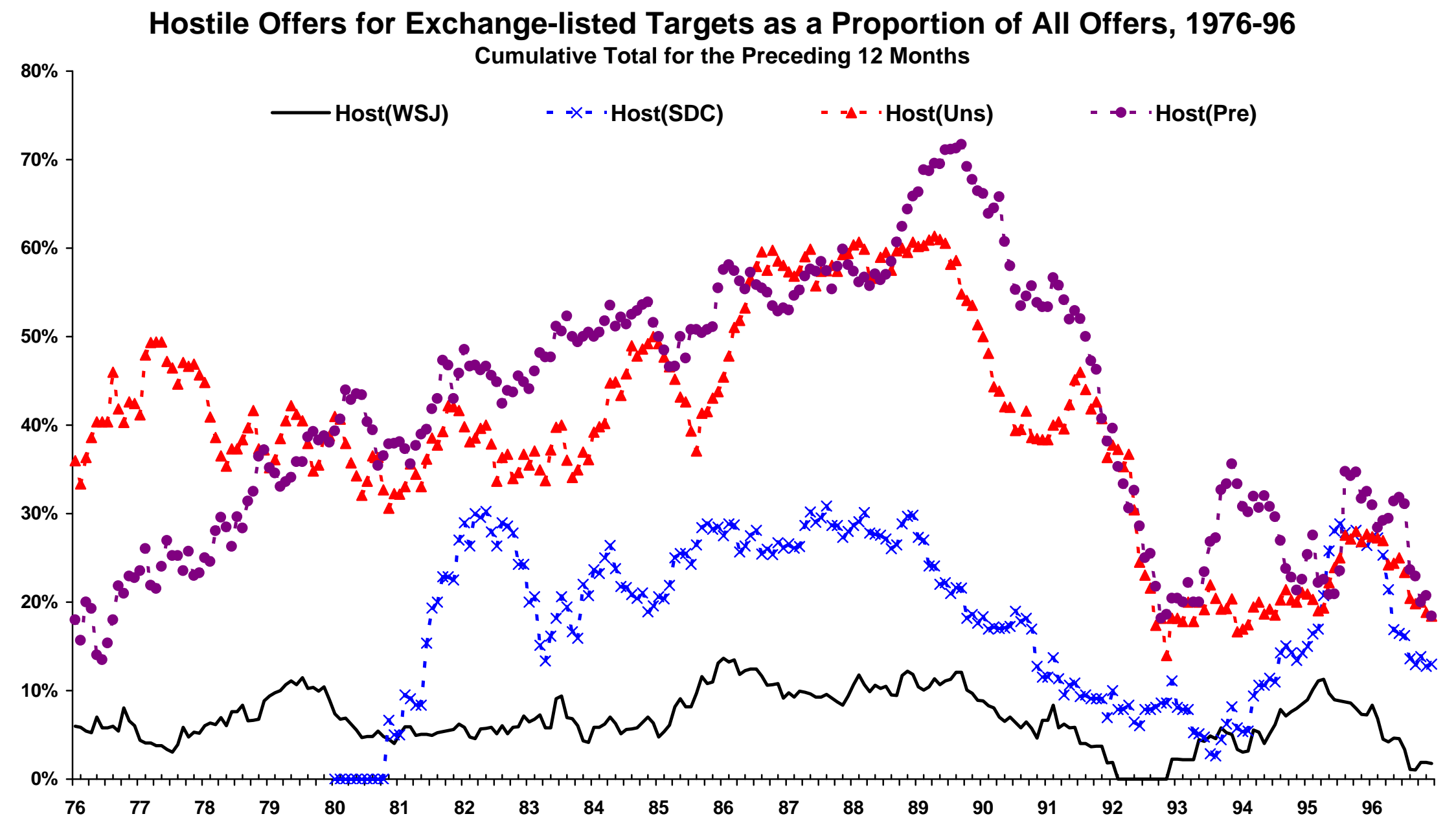

Figure 1. Proportion of all merger or tender offers that are perceived as hostile, by year and by four measures of hostility, for exchange-listed target firms in the period 1975-96. Hostile offers are measured as all those ever explicitly characterized as such in a Wall Street Journal or Dow Jones News Retrieval story [Host(WSJ)], all those characterized as such by Securities Data Corporation [Host(SDC)], all those where the initial or the winning offer is unsolicited [Host(Uns)], and all those where during the prior year there was an initial Form 13D filing or a WSJ or DJNR story about takeover rumors [Host(Pre)]. 


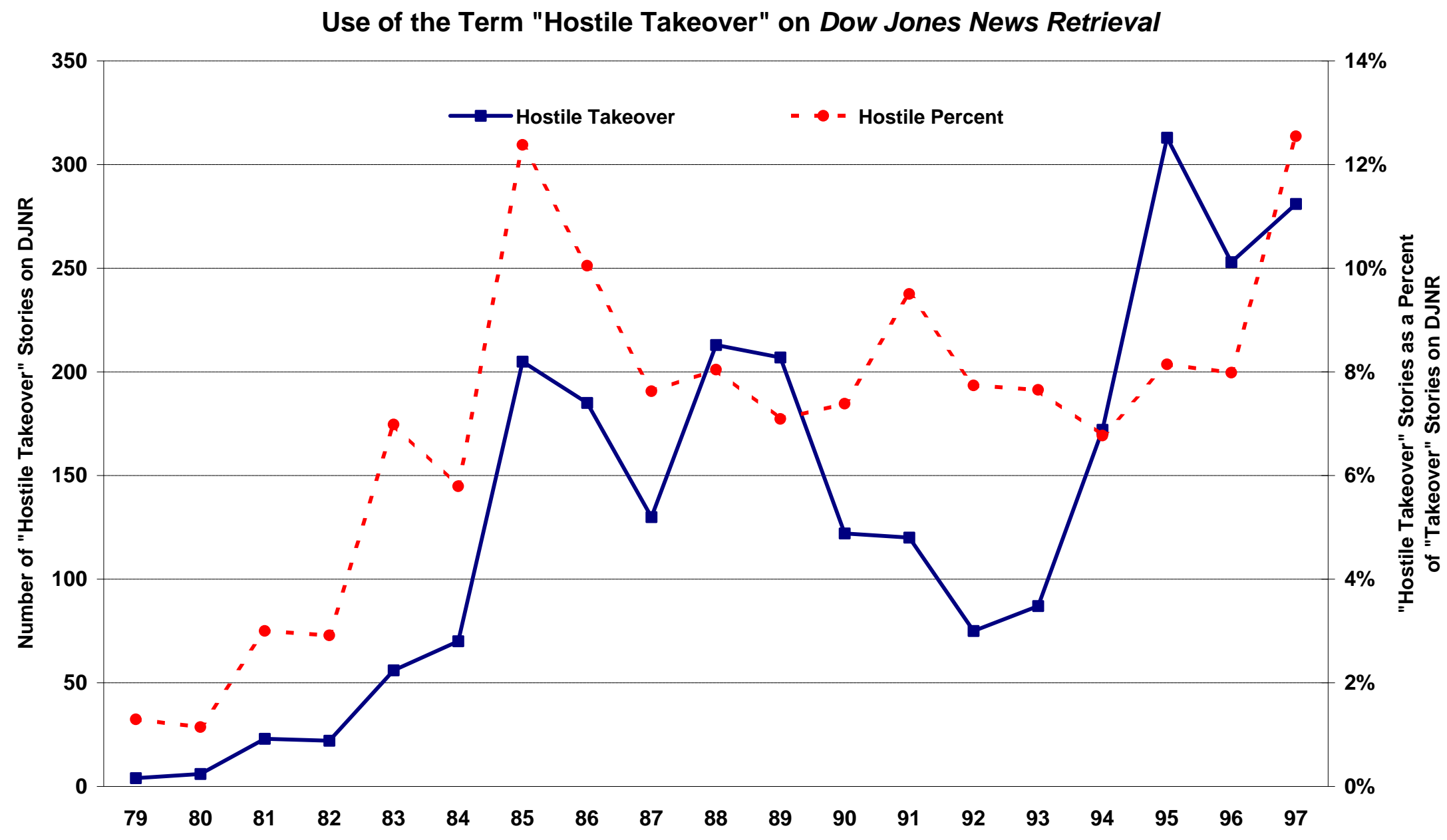

Figure 2. The number of Dow Jones News Retrieval stories containing the adjective "Hostile" modifying the noun "Takeover" in the period November 1979 - June 1997. Also, the proportion of "Takeover" stories containing "Hostile." 


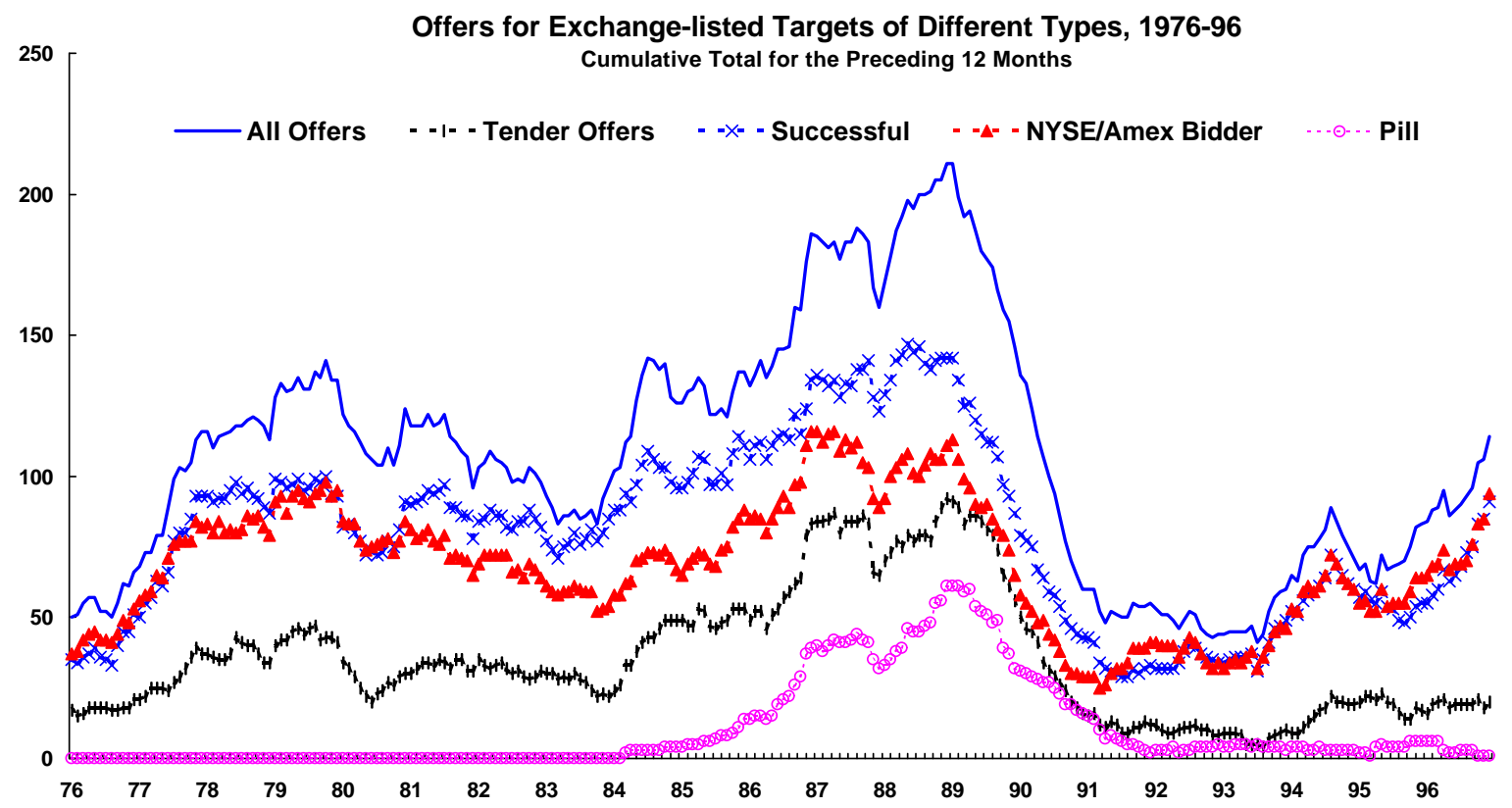

Proportion of Offers for Exchange-listed Targets of Different Types, 1976-96 Cumulative Total for the Preceding 12 Months

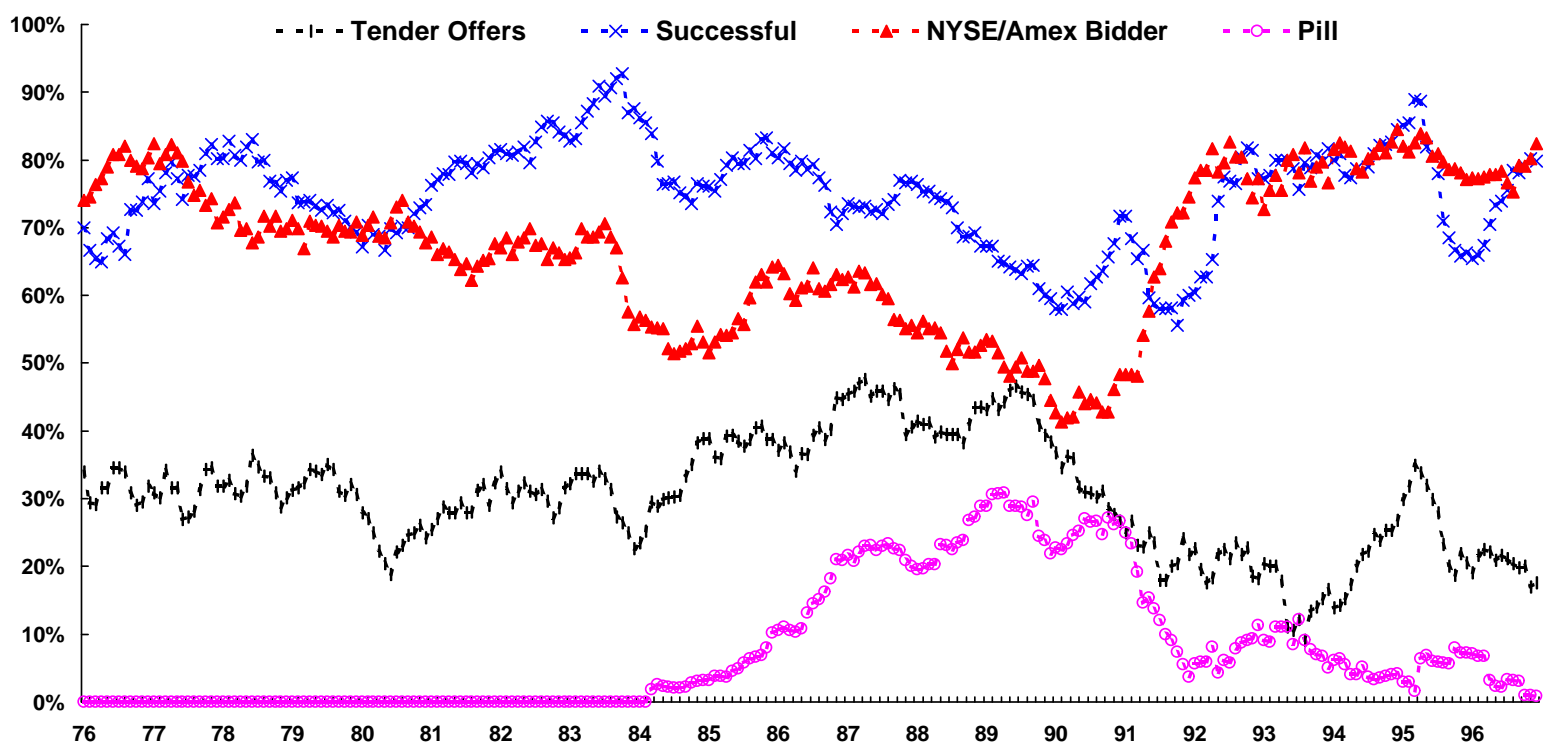

Figure 3. Number (top panel) and proportion (bottom panel) of merger or tender offers that were (1) tender offers, (2) successful, (3) made by an exchange-listed public firm (NYSE or Amex bidder), and (4) for target firms that had a poison pill as an antitakeover measure, by year for exchange-listed target firms in the period 1975-96. Successful offers are ones where the target firm was acquired by some buyer within one year of the offer. 


\section{Cumulative Abnormal Returns to Bidders' Stocks}

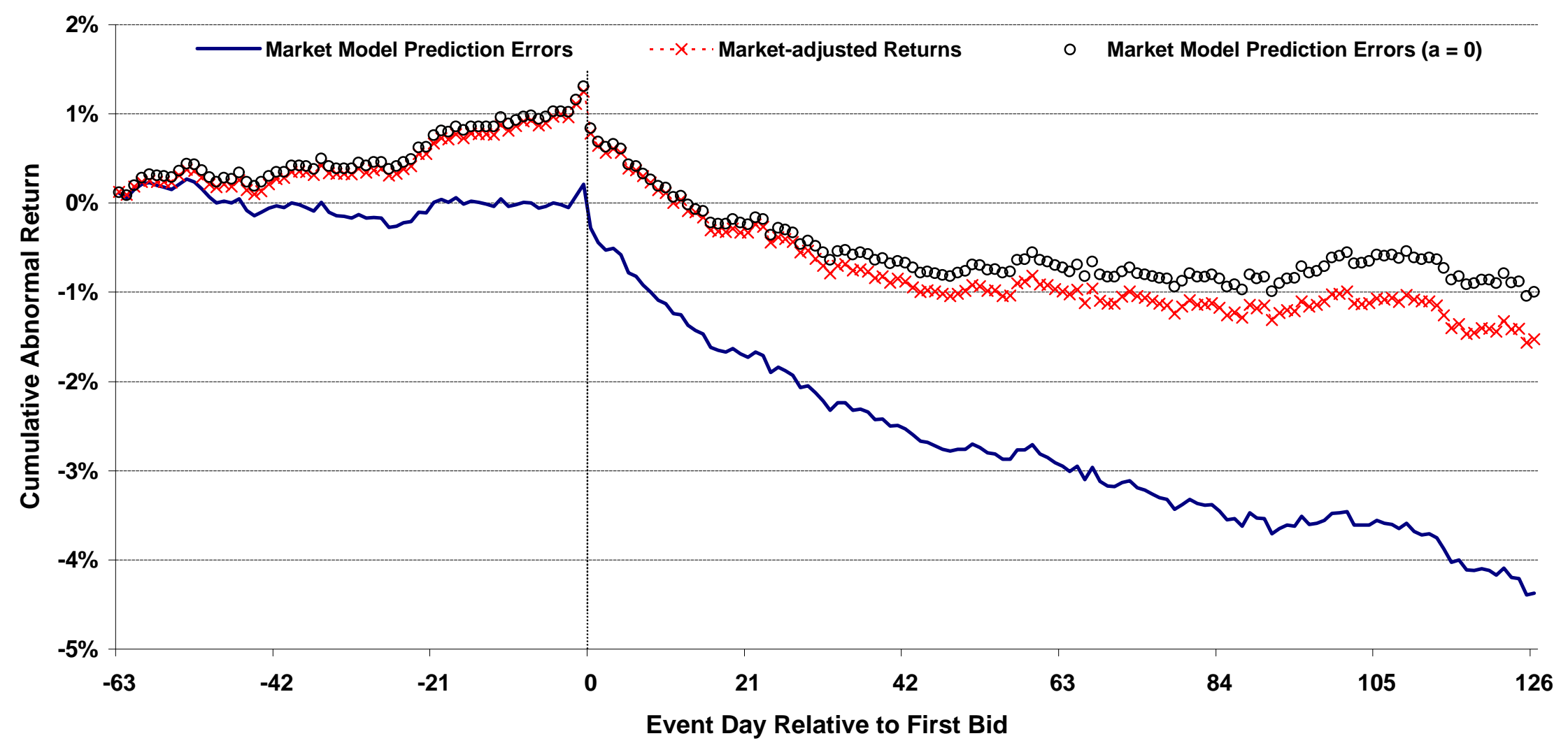

Figure 4. Cumulative Abnormal Returns to bidders' stocks from day -63 to day 126 relative to the first bid. Abnormal returns are calculated using three methods. The Market Model Prediction Errors use regression estimates from trading days -316 to -64. Market Model Prediction Errors (alpha $=0$ ) subtract the CRSP value-weighted market return times the estimate of beta from the market model regression from the bidder's stock return (i.e., they assume alpha is zero). Market-adjusted returns assume that alpha $=0$ and beta $=1$. This plot shows that the downward drift in cumulative Market Model Prediction Errors, which are based on actual estimates of alpha, is attributable to unusually high estimates of alpha, representing good stock price performance for bidders before they make takeover offers. 